\title{
Oxidation capacity of the city air of Santiago, Chile
}

\author{
Y. F. Elshorbany ${ }^{1,2}$, R. Kurtenbach ${ }^{1}$, P. Wiesen ${ }^{1}$, E. Lissi ${ }^{3}$, M. Rubio ${ }^{3}$, G. Villena ${ }^{3}$, E. Gramsch ${ }^{4}$, A. R. Rickard ${ }^{5}$, \\ M. J. Pilling ${ }^{6}$, and J. Kleffmann ${ }^{1}$ \\ ${ }^{1}$ Physikalische Chemie, FB C, Bergische Universität Wuppertal, Gaußstraße 20, 42119 Wuppertal, Germany \\ ${ }^{2}$ Environmental Sciences Division, National Research Center, Dokki, Giza, Egypt \\ ${ }^{3}$ Faculty of Chemistry and Biology, University of Santiago de Chile, USACH, Alameda L. Bernardo O'Higgins 3363, \\ Santiago, Chile \\ ${ }^{4}$ Physics Department, Faculty of Science, University of Santiago de Chile, Alameda L. Bernardo O'Higgins 3363, \\ Santiago, Chile \\ ${ }^{5}$ National Centre for Atmospheric Science, University of Leeds, Leeds, UK \\ ${ }^{6}$ School of Chemistry, University of Leeds, Leeds, UK
}

Received: 8 July 2008 - Published in Atmos. Chem. Phys. Discuss.: 14 November 2008

Revised: 24 February 2009 - Accepted: 19 March 2009 - Published: 27 March 2009

\begin{abstract}
The oxidation capacity of the highly polluted urban area of Santiago, Chile has been evaluated during a summer measurement campaign carried out from 8-20 March 2005 . The hydroxyl $(\mathrm{OH})$ radical budget was evaluated employing a simple quasi-photostationary-state model (PSS) constrained with simultaneous measurements of HONO, $\mathrm{HCHO}, \mathrm{O}_{3}, \mathrm{NO}, \mathrm{NO}_{2}, j\left(\mathrm{O}^{1} \mathrm{D}\right), j\left(\mathrm{NO}_{2}\right), 13$ alkenes and meteorological parameters. In addition, a zero dimensional photochemical box model based on the Master Chemical Mechanism (MCMv3.1) has been used to estimate production rates and total free radical budgets, including $\mathrm{OH}, \mathrm{HO}_{2}$ and $\mathrm{RO}_{2}$. Besides the above parameters, the MCM model has been constrained by the measured $\mathrm{CO}$ and volatile organic compounds (VOCs) including alkanes and aromatics. Both models simulate the same $\mathrm{OH}$ concentration during daytime indicating that the primary $\mathrm{OH}$ sources and sinks included in the simple PSS model predominate. Mixing ratios of the main $\mathrm{OH}$ radical precursors were found to be in the range 0.8 $7 \mathrm{ppbv}$ (HONO), 0.9-11 ppbv (HCHO) and 0-125 ppbv $\left(\mathrm{O}_{3}\right)$. The alkenes average mixing ratio was $\sim 58 \mathrm{ppbC}$ accounting for $\sim 12 \%$ of the total identified non-methane hydrocarbons (NMHCs). During the daytime (08:00 h-19:00 h), HONO photolysis was shown to be the most important primary $\mathrm{OH}$ radical source comprising alone $\sim 55 \%$ of the total initial production rate, followed by alkene ozonolysis $(\sim 24 \%)$ and
\end{abstract}

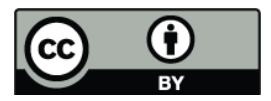

Correspondence to: J. Kleffmann (kleffman@uni-wuppertal.de) photolysis of $\mathrm{HCHO}(\sim 16 \%)$ and $\mathrm{O}_{3}(\sim 5 \%)$. The calculated average and maximum daytime $\mathrm{OH}$ production rates from HONO photolysis was $1.7 \mathrm{ppbv} \mathrm{h}^{-1}$ and $3.1 \mathrm{ppbvh}^{-1}$, respectively. Based on the experimental results a strong photochemical daytime source of $\mathrm{HONO}$ is proposed. A detailed analysis of the sources of $\mathrm{OH}$ radical precursors has also been carried out.

\section{Introduction}

The physical and chemical properties of the atmosphere are influenced by the presence of trace gases like nitrogen oxides $\left(\mathrm{NO}_{\mathrm{x}}\right)$ and volatile organic compounds (VOCs). The oxidising capacity of the atmosphere determines the rate of their removal (Prinn, 2003), and hence controls the abundance of these trace gases. Understanding the processes and rates by which species are oxidized in the atmosphere is thus crucial to our knowledge of the atmospheric composition of harmful and climate forcing species. The term "oxidation capacity", OC is defined in the current study as the sum of the respective oxidation rates of the molecules $\mathrm{Y}_{i}\left(\mathrm{VOCs}, \mathrm{CO}, \mathrm{CH}_{4}\right)$ by the oxidant $\mathrm{X}\left(\mathrm{X}=\mathrm{OH}, \mathrm{O}_{3}, \mathrm{NO}_{3}\right)$ (Geyer et al., 2001):

$\mathrm{OC}=\sum k_{\mathrm{Yi}}\left[\mathrm{Y}_{\mathrm{i}}\right][\mathrm{X}]$,

where $k_{Y_{i}}$ is the bi-molecular rate constant for the reaction of $\mathrm{Y}_{\mathrm{i}}$ with $\mathrm{X}$.

In addition, the concentrations of the oxidant species $\left(\mathrm{O}_{3}\right.$, $\mathrm{OH}, \mathrm{NO}_{3}$ ) was also used as important indicators and key

Published by Copernicus Publications on behalf of the European Geosciences Union. 
measure of the atmospheric oxidation capacity (Liu et al., 1988). However, since the life time of the trace gases is controlled not only by the oxidant concentration but also by its second-order rate constant $\left(k_{\mathrm{Yi}}\right)$, the method of Geyer et al. (2001) is most suitable to calculate the relative importance of each oxidant in the current study. Otherwise, $\mathrm{O}_{3}$ (of the highest concentration among the oxidizing species) would be always the most important oxidant. Recently, a comparable method based on the reciprocal of the life time $(1 / \tau)$ of the oxidized species $\left(\mathrm{Y}_{\mathrm{i}}\right)$ was also used to express the total oxidation capacity (Cheng et al., 2008).

The hydroxyl radical $(\mathrm{OH})$ is the primary oxidant in the atmosphere, responsible for the oxidation and removal of most natural and anthropogenic trace gases. In addition, initiating oxidation by reaction with the $\mathrm{OH}$ radical leads to the formation of harmful oxidants, such as ozone $\left(\mathrm{O}_{3}\right)$ and peroxyacetylnitrate (PAN). Thus, the identification and quantification of the different atmospheric $\mathrm{OH}$ radical sources and sinks is of paramount importance. Primary sources of the $\mathrm{OH}$ radical include the photolysis of ozone followed by the subsequent reaction of the excited $\mathrm{O}^{1} \mathrm{D}$ atom with water, photolysis of formaldehyde (HCHO) in the presence of nitrogen oxide (NO), direct photolysis of nitrous acid (HONO) and the reactions of unsaturated hydrocarbons with $\mathrm{O}_{3}$. Ren et al. (2003) recently calculated the relative importance of the above sources of $\mathrm{OH}$ in New York and estimated HONO photolysis contributed up to $\sim 60 \%$. In other field work studies, unexpected high daytime values of HONO were observed (e.g. Zhou et al., 2002; Kleffmann et al., 2002, 2005; Acker et al., $2006 \mathrm{a}, \mathrm{b}$ ) and new photochemical HONO sources have been proposed (Kleffmann, 2007), some of which have recently been identified in the laboratory (Zhou et al., 2003; George et al., 2005; Stemmler et al., 2006, 2007; Bejan et al., 2006; Li et al., 2008).

Summertime urban $\mathrm{OH}$ and $\mathrm{HO}_{2}$ radical budgets have been evaluated in several field campaigns (e.g., George et al., 1999; Holland et al., 2003; Ren et al., 2003; Heard et al., 2004; Volkamer et al., 2007; Emmerson et al., 2007; Kanaya et al., 2007). In most of these studies, the experimental measurements were complemented with model simulations in order to understand the chemical mechanisms that control tropospheric urban chemistry. Interestingly, the urban daytime $\mathrm{OH}$ and $\mathrm{HO}_{2}$ radical budgets have been shown to be better simulated during the summer rather than winter, especially for high $\mathrm{NO}_{\mathrm{x}}$ environments. Ren et al. (2006) used a box model incorporating the Regional Atmospheric Chemistry Mechanism, (RACM; Stockwell et al., 1997), which is based on the lumping technique to simulate radical budgets in New York during a winter campaign carried out in 2004 and obtained a median measured to model ratio of 0.98 for $\mathrm{OH}$. However, the RACM model significantly underestimated $\mathrm{HO}_{2}$, both during day and at night, with median measured to model ratio of 6.0. Similarly, during the IMPACT campaign in Tokyo the RACM model reproduced wintertime $\mathrm{OH}$ well but underestimated the $\mathrm{HO}_{2}$ by a median factor of 2 .
However, during the summer, the RACM model generally reproduced the daytime $\mathrm{OH}$ and $\mathrm{HO}_{2}$ reasonably well (Kanaya et al., 2007). For Mexico City, Shirley et al. (2006) reported a median measured to model $\mathrm{OH}$ ratio of 1.07 during the morning and night and 0.77 during the rush hour using the RACM model. For $\mathrm{HO}_{2}$, median measured to model ratios of $1.17,0.79$ and 1.27 were determined during the morning rush hour, midday and night, respectively. Besides lumped mechanisms, the more explicit Master Chemical Mechanism, MCM (http://mcm.leeds.ac.uk/MCM/; Jenkin et al., 1997; Saunders et al., 2003; Bloss et al., 2005) has been used extensively to interpret field measurements, carried out under a variety of conditions, including urban environments (e.g. Mihelcic et al., 2003; Emmerson et al., 2005a, b, 2007). During the BERLIOZ campaign, which took place in Berlin in August 1998 (Mihelcic et al., 2003), the hydroxyl and peroxy radical $\left(\mathrm{RO}_{2}\right)$ budgets have been measured and compared to those calculated by a photochemical box model containing the MCM. The modelled $\mathrm{OH}$ concentrations were found to be in excellent agreement with the measurements under high- $\mathrm{NO}_{\mathrm{x}}$ conditions $\left(\mathrm{NO}_{\mathrm{x}}>10 \mathrm{ppbv}\right)$. The measured $\mathrm{RO}_{2} / \mathrm{HO}_{2}$ ratio was also well reproduced by the model. The MCM modelled radical concentrations during the TORCH campaign, which took place $\sim 40 \mathrm{~km} \mathrm{NE}$ of central London in the summer of 2003 also agreed well with measurements with only a $24 \%$ and $7 \%$ over prediction for $\mathrm{OH}$ and $\mathrm{HO}_{2}$, respectively (Emmerson et al., 2007). During the majority of the summer campaign studies reported in the literature the daytime peak $\mathrm{OH}$ is well simulated, in the range of (310) $\times 10^{6}$ molecule $\mathrm{cm}^{-3}$ (Kanaya et al., 2007 and references therein). However, model $\mathrm{OH}$ production rate analysis has suffered from high uncertainties due to the use of estimated HONO concentrations rather than accurate direct simultaneous measurements (e.g. Heard et al., 2004; Emmerson et al., 2005b, 2007; Kanaya et al., 2007). Using an MCM constrained box model with estimated HONO concentrations, the diurnally averaged $\mathrm{OH}$ concentrations during the summer of 1999 PUMA field campaigns in Birmingham city centre was underestimated by a factor of $\sim 2$ during the day especially under high $\mathrm{NO}_{\mathrm{x}}$ conditions (Emmerson et al., 2005a). This could potentially be due to an underestimation of daytime HONO concentrations from using only known gas phase chemistry (Kleffmann et al., 2005). Thus, other photochemical sources have been proposed and recently identified in the laboratory, e.g. by the photochemical heterogeneous conversion of $\mathrm{NO}_{2}$ on natural surfaces (George et al., 2005; Stemmler et al., 2006, 2007). The net HONO photolysis (defined as the HONO photolysis rate minus the radical loss rate due to the reaction $\mathrm{OH}+\mathrm{NO}$ ) was not a net source of $\mathrm{OH}$ radicals in the atmosphere when the reaction of $\mathrm{NO}+\mathrm{OH}$ was assumed as the unique HONO source in Birmingham city centre (Heard et al., 2004). Emmerson et al. (2005a, 2007) incorporate a parameterization for the heterogeneous conversion of $\mathrm{NO}_{2}$ into $\mathrm{HONO}$ on aerosol surfaces in their MCM model. As a result, an increase in $\mathrm{OH}$ concentration by only 
Table 1. Instrumentations used during the Santiago de Chile field campaign.

\begin{tabular}{|c|c|c|c|}
\hline Species & Method & Response time & Detection limit \\
\hline HONO & LOPAP-technique (Long-Path-Absorption Photometer) & $4 \mathrm{~min}$ & 3 pptv \\
\hline $\mathrm{HCHO}$ & $\begin{array}{l}\text { Hantzsch reaction based instrument, Aero Laser } \\
\mathrm{CH}_{2} \mathrm{O} \text { analyser (Model AL4001) }\end{array}$ & $3 \mathrm{~min}$ & $50 \mathrm{pptv}$ \\
\hline NO & $\begin{array}{l}\text { Chemiluminescence based analyzer with } \\
\text { molybdenum converter (Model TELEDYNE } 200 \text { E) }\end{array}$ & $<10 \mathrm{~s}$ & 400 pptv \\
\hline $\mathrm{NO}_{2}$ & DOAS-OPSIS optical system & $2 \min$ & $0.5 \mathrm{ppbv}$ \\
\hline $\mathrm{O}_{3}^{\mathrm{a}}$ & $\begin{array}{l}\text { Short-path UV absorption }(\lambda=254 \mathrm{~nm}) \text {, } \\
\text { from Advanced Pollution Instruments Model } 400 .\end{array}$ & $10 \mathrm{~s}$ & $1 \mathrm{ppbv}$ \\
\hline $\mathrm{O}_{3}^{\mathrm{b}}$ & UV absorption based monitor (Dasibi Model 1009-Cp) & $10 \mathrm{~s}$ & $1 \mathrm{ppbv}$ \\
\hline $\mathrm{CO}^{\mathrm{a}}$ & IR absorption based monitor (Interscan 4000) & $20 \mathrm{~s}$ & $1 \mathrm{ppb}$ \\
\hline PAN & GC-ECD (Meteorolgie Consult GmbH) & $10 \mathrm{~min}$ & 25 pptv \\
\hline$j\left(\mathrm{NO}_{2}\right), j\left(\mathrm{O}^{1} \mathrm{D}\right)$ & Filter radiometers (Meteorolgie Consult $\mathrm{GmbH}$ ) & $1 \mathrm{~min}$ & - \\
\hline $\mathrm{C}_{3}-\mathrm{C}_{10} \mathrm{NMHCs}$ & $\begin{array}{l}\text { GC-FID analysis (HP Model 6890) following } \\
\text { the US Compendium Method TO-17 (EPA) }\end{array}$ & $3 \mathrm{~h}$ (day) and $6 \mathrm{~h}$ (night) & 37 pptv (4-77 pptv) \\
\hline
\end{tabular}

${ }^{a}$ Measured at the Park O'Higgins station (POH) $1.8 \mathrm{~km}$ southeast of the USACH measurement site.

${ }^{\mathrm{b}}$ Used to investigate the ozone interferences during the VOC sampling process.

$0.03 \%$ (Emmerson et al., 2005a) and a net contribution of HONO to the radical production of $3 \%$ during hot and stagnant "heatwave" conditions of the TORCH campaign (Emmerson et al., 2007) were calculated. A similar contribution of 3\% was estimated in Tokyo assuming heterogeneous production of $\mathrm{HONO}$ by dry deposition of $\mathrm{NO}_{2}$ to the ground with $\mathrm{HONO}$ subsequently produced according to the reaction $2 \mathrm{NO}_{2}+\mathrm{H}_{2} \mathrm{O} \rightarrow \mathrm{HONO}+\mathrm{HNO}_{3}$ (Kanaya et al., 2007). During the LAFRE campaign in California, 1993 (George et al., 1999), a significant reduction in both modelled $\mathrm{OH}$ and $\mathrm{HO}_{2}$ has been observed when heterogeneous HONO formation on ground surfaces was removed from the model, especially in the morning. Similarly, in BERLIOZ, the RACM model predicted only $50 \%$ of the measured $\mathrm{OH}$ concentrations when HONO photolysis was switched off in the early morning (Alicke et al., 2003). It is clear, therefore, that the simultaneous measurement of HONO, along side other major radical precursors, is crucial in the analysis of atmospheric radical budgets (e.g. Ren et al., 2003; Kleffmann et al., 2003; Acker et al., 2006a, b).

Several studies focusing on air quality issues in Santiago de Chile have shown that severe air quality problems, including the photochemical formation of large amounts of ozone, PAN and related photooxidants, have a significant impact on health problems in the city (Rappenglück et al., 2000; Rubio et al., 2004; Rappenglück et al., 2005). However, none of these studies have observed the diurnal variation of the important $\mathrm{OH}$ radical precursor $\mathrm{HONO}$.

The work reported here focuses on the analysis of a comprehensive suite of data taken during a summertime field campaign carried out in the city of Santiago de Chile from 820 March 2005. This work constitutes the first detailed evaluation of photochemistry in Santiago, Chile that takes into account all the major primary $\mathrm{OH}$ radical sources, namely the photolysis of HONO, formaldehyde (HCHO) and ozone $\left(\mathrm{O}_{3}\right)$ and the dark reactions of ozone with alkenes, in addition to peroxy radical $\left(\mathrm{HO}_{2}\right.$ and $\left.\mathrm{RO}_{2}\right)$ recycling reactions. Under the high $\mathrm{NO}_{\mathrm{x}}$ conditions often experienced in Santiago (Elshorbany et al., 2009), a constrained photochemical box model based around the MCM and a simple photo-stationary steady state (PSS) model were used to evaluate radical budgets and their source apportionment during late summer in order to understand the photochemistry occurring in such a highly polluted urban environment as Santiago.

\section{Methodology}

\subsection{Measurement site}

The measurements were performed downtown of the city of Santiago, Chile, on the third floor of the Physics Department of the University of Santiago (USACH) and in the Park O'Higgins station (POH), situated $\sim 1.8 \mathrm{~km}$ southeast of the main USACH measurement site. The city of Santiago de Chile is located at $-33.45^{\circ}$ latitude and $70.67^{\circ}$ longitude, $\sim 550 \mathrm{~m}$ above sea level and surrounded by two mountain ranges, the Andes and the Cordillera de la Costa.

\subsection{Measurement techniques}

The techniques used to measure the different parameters are listed in Table 1 with their response times and detection limits. At the USACH site HONO was measured by the sensitive LOPAP (Long Path Absorption Photometer) technique (Heland et al., 2001; Kleffmann et al., 2002). The LOPAP instrument was recently intercompared against the DOAS 
technique, both in a smog chamber and in the urban atmosphere. Excellent agreement was obtained under daytime photochemical smog conditions (Kleffmann et al., 2006), in contrast to other intercomparison studies (e.g., Appel et al., 1990; Spindler et al., 2003). The excellent agreement can be explained by the active correction of interferences and the use of an external sampling unit, minimizing artefacts in sampling lines. Potential heterogeneous HONO formation on the walls of the USACH building on which the sampling unit was fixed $(\sim 130 \mathrm{~cm}$ distance), was also investigated. No significant variation of the HONO concentration was observed when varying the distance of the sampling unit $(20-150 \mathrm{~cm})$ from the wall.

Other measured parameters at the USACH site included $\mathrm{HCHO}, \mathrm{NO}, \mathrm{NO}_{2}, \mathrm{PAN}$ and photolysis frequencies $j\left(\mathrm{NO}_{2}\right)$ and $j\left(\mathrm{O}^{1} \mathrm{D}\right)$. The photolysis frequencies of $\mathrm{HCHO}$ and HONO were calculated from the measured $j\left(\mathrm{NO}_{2}\right)$ and $j\left(\mathrm{O}^{1} \mathrm{D}\right)$ data (Holland et al., 2003). The parameterization by Holland et al. (2003) cover a variety of meteorological conditions (zenith angle $=31^{\circ}-90^{\circ}, 300-400 \mathrm{DU}$ total ozone, $0-8$ octa cloud cover, $6^{\circ}-28^{\circ} \mathrm{C}$ ambient temperature). In Santiago, the average campaign maximum zenith angle of $32^{\circ}$, annual mean (1979-2004) total ozone column of $281 \pm 8$ DU (Diaz et al., 2006), clear sky and ambient temperature range of $12^{\circ}-32^{\circ} \mathrm{C}$, lies within the range of meteorological parameters used to generate the $j$-parameterization by Holland et al., 2003 justifying its use.

$\mathrm{O}_{3}, \mathrm{CO}$ and meteorological data were obtained from the POH station. $\mathrm{C}_{3}-\mathrm{C}_{10} \mathrm{NMHC}$ were sampled at the USACH site on adsorption tubes and analyzed by GC-FID analysis following the US EPA Compendium Method TO-17 (see Table 2). The detailed analytical procedure is published elsewhere (Niedojadlo et al., 2007). The ambient NMHCs have been sampled using an automatic system equipped with calibrated regulated flow controllers and applying an air flow of $20 \mathrm{ml} / \mathrm{min}$ on the adsorbing tubes. After sampling, the adsorption tubes were capped with Parafilm, stored in air sealed glass tubes in the refrigerator and returned to Germany for GC-FID analysis. Potential ozone interferences have been tested in the laboratory by sampling a standard VOC mixture over the same type of adsorption tubes with and without addition of ozone at a mixing ratio of 135 ppbv. Sampling periods of three hours were chosen using NMHCs mixing ratios corresponding to the minimum observed NMHCs mixing ratios during the measurement campaign. Ozone was prepared by passing a regulated flow of pure synthetic air through a mercury UV-lamp based ozoniser followed by a reaction vessel with glass rings cooled with dry ice to $203 \mathrm{~K}$ in order to trap the $\mathrm{HO}_{\mathrm{x}}$ radicals from the ozonised air. Ozone has been monitored by a commercial UV absorption based monitor (Table 1). Only reductions of as low as $-8.8 \%$ for trans2-butene and as high as $-29.4 \%$ for cis-2-pentene were observed. The average and median $\mathrm{O}_{3}$ values (averaged over the same time intervals of the VOC samples) were only 26 and 21 ppbv, respectively. Thus, we exclude significant neg- ative interferences from ozone. This result is in agreement with the study of Koppmann et al. (1995) who found no significant interferences from ozone up to mixing ratios of $100 \mathrm{ppbv}$ either using pressurized air samples or cryogenically collected air samples even at very low VOC concentrations.

\subsection{Modelling approach}

\subsubsection{Simple Quasi-Photostationary State Model, PSS}

$\mathrm{OH}$ concentrations were calculated with the steady-state approximation using the radical production rates from HONO, $\mathrm{HCHO}$ and ozone photolysis, alkenes ozonolysis and the radical loss rate. Under the prevailing high $\mathrm{NO}_{\mathrm{x}}$ conditions radical loss is mainly governed by the reactions of $\mathrm{OH}$ with $\mathrm{NO}_{\mathrm{x}}$ (c.f. George et al., 1999; Ren et al., 2006; Emmerson et al., 2005b, 2007; Kanaya et al., 2007). During the day, formation of $\mathrm{HONO}$ by reaction of $\mathrm{OH}$ with $\mathrm{NO}$ is essentially balanced by photolysis of HONO formed from this reaction. Radical removal by peroxy-peroxy radical reactions is unimportant under high $\mathrm{NO}_{\mathrm{x}}$ conditions (see Sect. 3.3). Thus, the net radical loss rate can be estimated from the rate of reaction of $\mathrm{OH}$ with $\mathrm{NO}_{2}$ :

$\mathrm{L}_{\mathrm{R}}=k_{\mathrm{NO}_{2}+\mathrm{OH}}\left[\mathrm{NO}_{2}\right][\mathrm{OH}]$

The applied steady state approximation can be summarized as follows:

$\mathrm{P}_{\mathrm{R}}=\mathrm{L}_{\mathrm{R}}$.

The total rate of radical initiation, $\mathrm{P}_{\mathrm{R}}$, is given by:

$\mathrm{P}_{\mathrm{R}}=\mathrm{P}_{\mathrm{OH}}($ prim $)-\mathrm{k}_{\mathrm{OH}+\mathrm{NO}}[\mathrm{NO}][\mathrm{OH}]+\mathrm{P}_{\mathrm{HO}_{2}}($ prim $)$,

for which:

$\mathrm{P}_{\mathrm{OH}}($ prim $)=j(\mathrm{HONO})[\mathrm{HONO}]+j\left(\mathrm{O}^{1} \mathrm{D}\right)\left[\mathrm{O}_{3}\right] \Phi_{\mathrm{OH}}+$

$\Sigma k_{\mathrm{O}_{3}+\text { alkene }}\left[\right.$ alkene][ $\left.\mathrm{O}_{3}\right] \Phi_{\mathrm{OH}}$,

$\mathrm{P}_{\mathrm{HO}_{2}}($ prim $)=2 j\left(\mathrm{HCHO}_{\text {radical }}\right)[\mathrm{HCHO}]$.

For ozone photolysis $\Phi_{\mathrm{OH}}$ (defined here as the fraction of $\mathrm{O}^{1} \mathrm{D}$ produced that will react with $\mathrm{H}_{2} \mathrm{O}$ rather than is quenched to ground state $\mathrm{O}^{3} \mathrm{P}$ ) was calculated using known rate constants for $\mathrm{O}^{1} \mathrm{D}$ quenching and reaction with water in addition to the measured water concentration. For the alkene ozonolysis reactions $\Phi_{\mathrm{OH}}$ represents the $\mathrm{OH}$ yield from the respective reactions (e.g. Rickard et al., 1999).

Therefore, the steady state $\mathrm{OH}$ concentration is given by:

$[\mathrm{OH}]_{\mathrm{PSS}}=\mathrm{P}_{\mathrm{R}} /\left(k_{\mathrm{NO}_{2}+\mathrm{OH}}\left[\mathrm{NO}_{2}\right]\right)$. 
Table 2. List of the VOCs measured during the summer campaign in Santiago de Chile.

\begin{tabular}{|c|c|c|c|c|c|}
\hline \multirow[t]{2}{*}{$\mathrm{MCM}$} & \multirow[t]{2}{*}{ Compound name } & \multirow[t]{2}{*}{$\mathrm{D}_{L}(\mathrm{ppbv})$} & \multicolumn{3}{|c|}{ Mixing ratio (ppbv) } \\
\hline & & & $\operatorname{Max}$ & Average & Median \\
\hline$*$ & propene & 0.07 & 38.8 & 3.80 & 1.56 \\
\hline * & propane & 0.07 & 475 & 41.8 & 11.5 \\
\hline \multirow[t]{2}{*}{$*$} & i-butane (2-methylpropane) & 0.06 & 18.0 & 2.95 & 1.57 \\
\hline & 1-butene, i-butene & 0.20 & 9.2 & 2.35 & 2.04 \\
\hline$*$ & 1,3-butadien & 0.06 & 0.41 & 0.15 & 0.12 \\
\hline$*$ & n-butane & 0.04 & 18.3 & 3.89 & 2.32 \\
\hline$*$ & trans-2-butene & 0.04 & 0.86 & 0.18 & 0.11 \\
\hline$*$ & cis-2-butene & 0.04 & 0.67 & 0.16 & 0.10 \\
\hline$*$ & 3-methyl-1-butene & 0.05 & 1.22 & 0.19 & 0.14 \\
\hline$*$ & i-pentane (2-methylbutane) & 0.06 & 27.6 & 5.75 & 4.08 \\
\hline \multirow[t]{2}{*}{$*$} & 1-pentene & 0.01 & 1.77 & 0.30 & 0.18 \\
\hline & n-pentane, 2-methyl-1-butene & 0.06 & 18.8 & 2.03 & 0.82 \\
\hline$*$ & isoprene & 0.02 & 1.84 & 0.67 & 0.51 \\
\hline$*$ & trans-2-pentene & 0.01 & 1.41 & 0.24 & 0.14 \\
\hline$*$ & cis-2-pentene & 0.004 & 0.74 & 0.15 & 0.10 \\
\hline \multirow[t]{5}{*}{ * } & 2-methyl-2-butene & 0.04 & 2.10 & 0.33 & 0.20 \\
\hline & 2,2-dimethylbutane & 0.09 & 5.20 & 1.07 & 0.63 \\
\hline & cyclopentene & 0.02 & 0.17 & 0.05 & 0.04 \\
\hline & methyl-tert-butyl ether, 2,3-dimethylbutan, cyclopentan & 0.16 & 5.84 & 1.28 & 0.89 \\
\hline & 2-methylpentane & 0.06 & 14.4 & 3.11 & 1.94 \\
\hline * & 3-methylpentane & 0.05 & 6.09 & 1.40 & 0.92 \\
\hline \multirow[t]{4}{*}{$*$} & 1-hexene & 0.02 & 0.80 & 0.20 & 0.14 \\
\hline & n-hexan, 2-ethyl-1-butene & 0.06 & 5.31 & 1.36 & 0.94 \\
\hline & 2,3-dimethyl-1,3-butadiene & 0.02 & 0.15 & 0.05 & 0.03 \\
\hline & methylcyclopentane, 1-methyl-1-cyclopentene & 0.07 & 6.27 & 1.36 & 0.87 \\
\hline$*$ & 2,3-dimethyl-2-butene & 0.02 & 0.52 & 0.10 & 0.06 \\
\hline \multirow[t]{2}{*}{$*$} & benzene & 0.08 & 9.22 & 2.13 & 1.43 \\
\hline & cyclohexane, 2,3-dimethylpentane & 0.07 & 8.07 & 2.08 & 1.50 \\
\hline \multirow[t]{4}{*}{ * } & 2-methylhexane & 0.04 & 1.71 & 0.35 & 0.22 \\
\hline & cyclohexene & 0.05 & 0.39 & 0.13 & 0.10 \\
\hline & 1-heptene & 0.02 & 1.01 & 0.24 & 0.17 \\
\hline & 2,2,4-trimethylpentane & 0.03 & 3.81 & 0.92 & 0.68 \\
\hline \multirow[t]{3}{*}{$*$} & n-heptane & 0.02 & 2.50 & 0.55 & 0.42 \\
\hline & 1,4-cyclohexadiene & 0.04 & 0.14 & 0.07 & 0.06 \\
\hline & 2,3,4-trimethylpentane & 0.03 & 0.92 & 0.13 & 0.05 \\
\hline \multirow[t]{5}{*}{ * } & toluene & 0.01 & 32.7 & 6.30 & 4.11 \\
\hline & 2-methylheptane & 0.03 & 1.46 & 0.31 & 0.21 \\
\hline & 3-methylheptane & 0.02 & 0.57 & 0.10 & 0.07 \\
\hline & 4-methylheptane, 1-methyl-1-cyclohexene & 0.06 & 1.57 & 0.30 & 0.19 \\
\hline & 1-octene & 0.03 & 0.80 & 0.18 & 0.14 \\
\hline * & n-octane & 0.02 & 1.82 & 0.34 & 0.23 \\
\hline \multirow[t]{2}{*}{ * } & ethylbenzene & 0.02 & 6.06 & 1.38 & 1.14 \\
\hline & $\mathrm{m}-\& \mathrm{p}$-xylene & 0.04 & 22.2 & 5.14 & 4.26 \\
\hline * & styrene & 0.03 & 1.02 & 0.22 & 0.16 \\
\hline * & o-xylene & 0.04 & 7.72 & 1.81 & 1.50 \\
\hline * & $\alpha-$ pinene & 0.07 & 1.95 & 0.41 & 0.27 \\
\hline$*$ & n-propylbenzene & 0.02 & 1.68 & 0.36 & 0.26 \\
\hline * & 4-ethyltoluene & 0.01 & 1.40 & 0.30 & 0.21 \\
\hline$*$ & 1,3,5-trimethylbenzene & 0.03 & 2.79 & 0.58 & 0.38 \\
\hline \multirow[t]{2}{*}{$*$} & n-decane & 0.02 & 2.94 & 0.60 & 0.42 \\
\hline & 1,2,4-trimethylbenzene, tet. butylbenzene & 0.04 & 6.91 & 1.42 & 0.92 \\
\hline \multirow[t]{2}{*}{ * } & 1,2,3-trimethylbenzene & 0.01 & 1.31 & 0.27 & 0.17 \\
\hline & 1,2,3,4-tetramethylbenzene & 0.02 & 5.55 & 0.43 & 0.22 \\
\hline
\end{tabular}

\footnotetext{
* Compounds included in the MCM model (see Sect. 3.5).
} 


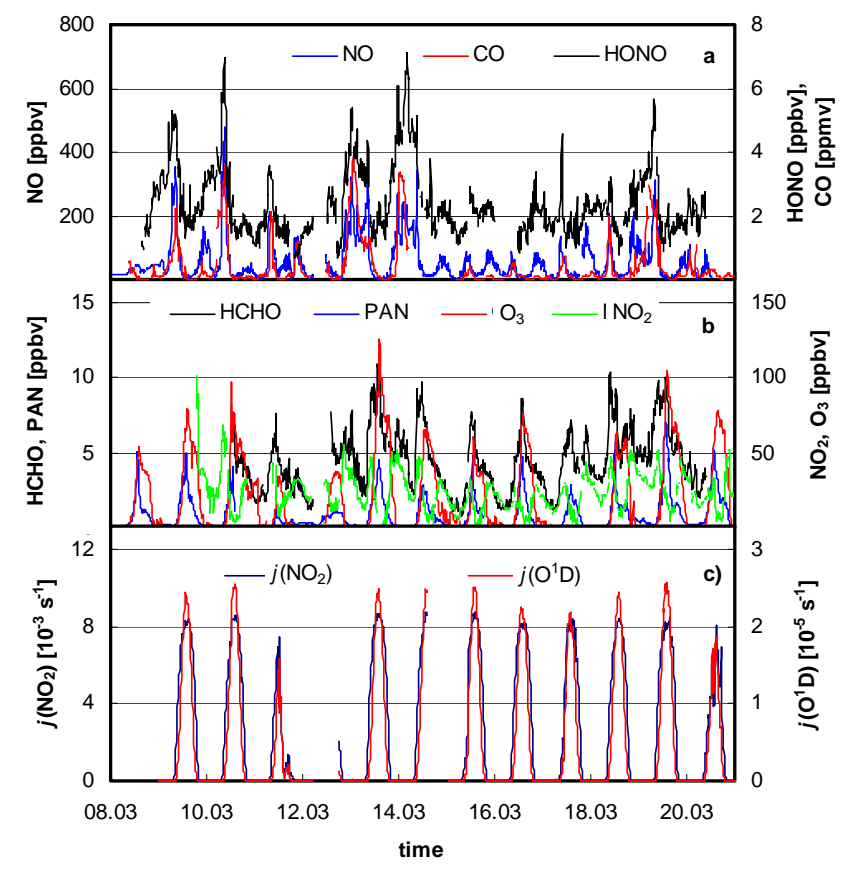

Fig. 1. $10 \mathrm{~min}$ average data of $\mathrm{HONO}, \mathrm{NO}, \mathrm{CO}, \mathrm{HCHO}, \mathrm{NO}_{2}, \mathrm{O}_{3}$, $j\left(\mathrm{NO}_{2}\right)$ and $j\left(\mathrm{O}^{1} \mathrm{D}\right)$ during the field campaign in Santiago de Chile, 8-20 March 2005.

\subsubsection{The Master Chemical Mechanism, MCM}

A zero dimensional photochemical box model based on the Master Chemical Mechanism, MCMv3.1 (http://mcm.leeds. ac.uk/MCM) has been used to evaluate the radical budgets. MCMv3.1 is a near-explicit chemical mechanism describing the detailed gas phase tropospheric degradation of methane and 135 primary emitted NMHCs, which leads to a mechanism containing ca. 5900 species and 13500 reactions. The mechanism is constructed according to a set of rules as defined in the latest mechanism development protocols (Jenkin et al. 1997; Jenkin et al., 2003, Saunders et al., 2003; Bloss et al., 2005). The MCM photochemical box model's system of simultaneous stiff ordinary differential equations (ODEs) was integrated with a variable order Gear's backward differentiation method (FACSIMILE; Curtis and Sweetenham, 1987). The model was constrained with average $10 \mathrm{~min}$ values of the following measured parameters: $j\left(\mathrm{NO}_{2}\right), j\left(\mathrm{O}^{1} \mathrm{D}\right)$, relative humidity, pressure, temperature, $\mathrm{NO}, \mathrm{NO}_{2}, \mathrm{HONO}, \mathrm{CO}, \mathrm{HCHO}, \mathrm{O}_{3}, \mathrm{PAN}$ and 31 NMHCs (see Table 2$). j(\mathrm{HONO})$ and $j\left(\mathrm{HCHO}_{\text {radical }}\right)$ were parameterized from the measured $j\left(\mathrm{NO}_{2}\right)$ and $j\left(\mathrm{O}^{1} \mathrm{D}\right)(\mathrm{Hol}-$ land et al., 2003) and their values have been constrained in the model. The other photolysis frequencies are parameterized within the model using a two stream isotropic scattering model under clear sky summertime conditions (Hayman, 1997; Saunders et al., 2003). The photolysis rates are calculated as a function of solar zenith angle and normalized by
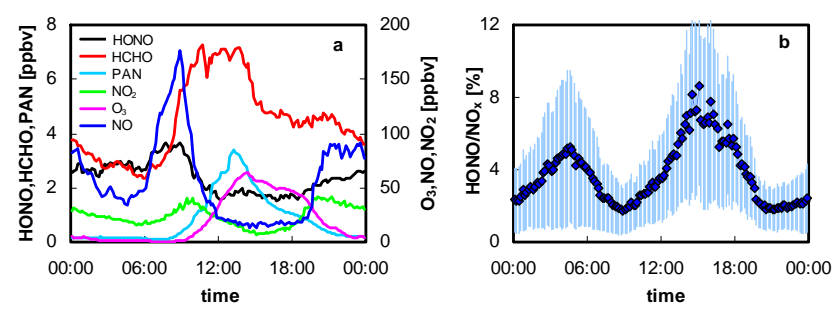

Fig. 2. (a) Average diurnal $10 \mathrm{~min}$ data of $\mathrm{HONO}, \mathrm{NO}, \mathrm{NO}_{2}, \mathrm{PAN}$, $\mathrm{O}_{3}$ and $\mathrm{HCHO}$ and (b) average diurnal $\mathrm{HONO} / \mathrm{NO}_{\mathrm{x}}$ ratio.

a scaling factor, calculated from the ratio of measured and model calculated $j\left(\mathrm{NO}_{2}\right)$ values, which takes into account the effects of varying cloud cover and aerosol scattering. A series of rate of production analyses (ROPA) were carried out in order to identify the most important photochemical processes driving the formation and loss of $\mathrm{OH}$ and $\mathrm{HO}_{2}$. The MCM photochemical model was run for a period of five days, with the model being constrained with the same measured campaign average parameters each day, in order to generate realistic concentrations for the unmeasured intermediate species. By the fifth day the free radicals in the model have reached a photostationary state, which has been used for the data evaluation.

\section{Results and discussion}

\subsection{Measurements results analysis}

For the data evaluation, all measurements were averaged over $10 \mathrm{~min}$ time intervals. The trace gases data of the whole campaign are shown in Fig. 1 while the 10 min average diurnal variation profiles are shown Fig. 2a. During the campaign sunny weather conditions were prevailing with temperatures ranging from $285 \mathrm{~K}$ to $305 \mathrm{~K}$ during the daytime. The wind speed was relatively low ranging from $0.2 \mathrm{~m} \mathrm{~s}^{-1}$ to $4.1 \mathrm{~m} \mathrm{~s}^{-1}$, and the average relative humidity was $49 \%$, reaching up to $100 \%$ during the night. The maximum HONO mixing ratio during rush hour reached $\sim 7 \mathrm{ppbv}$ on the 10th March at $\sim 9 \mathrm{~h}$. For the campaign averaged data maximum and minimum HONO mixing ratios of $3.7 \mathrm{ppbv}$ at around $8 \mathrm{~h}$ and $1.5 \mathrm{ppbv}$ around $17 \mathrm{~h}$ were obtained. For $\mathrm{CO}$ and $\mathrm{NO}$ a similar rush hour peak at $\sim 9 \mathrm{~h}$ on the 10th March was also observed with maximum concentrations of $3.6 \mathrm{ppmv}$ and $480 \mathrm{ppbv}$, respectively.

The average daytime rush hour maxima for $\mathrm{CO}$ and $\mathrm{NO}$ were $1.38 \mathrm{ppmv}$ and $180 \mathrm{ppbv}$, respectively (see Fig. 2a). The $\mathrm{NO}_{2}$ maximum was shifted later owing to small direct emissions and formation by the reaction of $\mathrm{NO}$ with peroxy radicals and $\mathrm{O}_{3}$. From the slope of the correlation plot of $\mathrm{HONO}$ against $\mathrm{NO}_{\mathrm{x}}$ a mean $\mathrm{HONO} / \mathrm{NO}_{\mathrm{x}}$ ratio of 0.008 was estimated during the rush hour peaks, which is 
in excellent agreement with direct tunnel measurements in Europe (Kurtenbach et al., 2001).

PAN, $\mathrm{HCHO}$ and $\mathrm{O}_{3}$ showed typical diurnal variations with average daytime maxima at about $14 \mathrm{~h}$ of $3 \mathrm{ppbv}, 7 \mathrm{ppbv}$ and $65 \mathrm{ppbv}$, respectively, demonstrating their photochemical formation. However, from the fast increase of $\mathrm{HCHO}$ in the early morning, when the $\mathrm{O}_{\mathrm{x}}\left(\mathrm{NO}_{2}+\mathrm{O}_{3}\right)$ increase was still small, a significant contribution from direct emissions was also identified (see Sect. 3.8.1). In addition to the maximum at $\sim 14 \mathrm{~h}$, the ozone diurnal variation profile is characterized with an afternoon shoulder at $18 \mathrm{~h}$, which has become a typical feature under photochemical smog conditions in Santiago (Rappenglück et al., 2000, 2005). The daytime HONO concentrations are significantly higher than in other polluted urban areas such as New York, Milan or Rome, where the minimum mean daytime concentrations were $0.3-0.6 \mathrm{ppbv}$ (Ren et al., 2003; Kleffmann et al., 2006; Acker et al., 2006b). The high mixing ratios and the daytime maximum of the $\mathrm{HONO} / \mathrm{NO}_{\mathrm{x}}$ ratio (see Fig. $2 \mathrm{~b}$ ) in Santiago points to a very strong daytime HONO source.

53 measured NMHCs have been identified (see Table 2). The remaining 127 unidentified NMHCs represents in average about $43 \%$ of the total measured NMHCs. Total average measured NMHCs of $\sim 900 \mathrm{ppbC}$ and known average measured NMHCs of $\sim 490 \mathrm{ppbC}$ were determined, which correspond to average diurnal $\mathrm{VOC} / \mathrm{NO}_{\mathrm{x}}$ ratios of 14 and 7, respectively. According to the $\mathrm{VOC} / \mathrm{NO}_{\mathrm{x}}$ ratio rule (Sillman, 1999) the first value corresponds to a $\mathrm{NO}_{\mathrm{x}}$-sensitive photochemical regime while the second correspond to a VOCsensitive photochemical regime. However, the $\mathrm{VOC} / \mathrm{NO}_{\mathrm{x}}$ ratio may not correctly represent the sensitivity of a photochemical regime. An explicit $\mathrm{VOC}-\mathrm{NO}_{\mathrm{x}}-\mathrm{O}_{3}$ sensitivity analysis showed that the photochemical regime in Santiago is clearly VOC sensitive (Elshorbany et al., 2009). Alkanes have the highest contribution (ppbC) to NMHCs (56\%) followed by aromatic hydrocarbons (32\%) and finally alkenes (12\%). The BTEX compounds (benzene, toluene, ethylbenzene and xylenes) contribute $\sim 80 \%$ of the total aromatic hydrocarbons and $\sim 25 \%$ of the total NMHCs.

\subsection{Oxidation capacity}

The loss rate of the VOCs and $\mathrm{CO}$ due to reactions with $\mathrm{OH}, \mathrm{O}_{3}$ and $\mathrm{NO}_{3}$ has been calculated using the MCM model. The average oxidation capacity of $\mathrm{OH}, \mathrm{O}_{3}$ and $\mathrm{NO}_{3}$ radicals through the entire day was $3.7 \times 10^{7}, 4.3 \times 10^{6}$ and $1.2 \times 10^{5}$ molecule $\mathrm{cm}^{-3} \mathrm{~s}^{-1}$ representing $89.4,10.3$ and $0.3 \%$ of the total oxidation capacity, respectively. Clearly, the $\mathrm{OH}$ radical was the dominant oxidant during daytime contributing by a maximum of $3.2 \times 10^{8}$ molecule $\mathrm{cm}^{-3} \mathrm{~s}^{-1}$ (94\%) to the total oxidation capacity at about $15 \mathrm{~h}$. The ozone contribution to the oxidation capacity during daytime ranged from $6 \%$ to $11 \%$ while it reached $>50 \%$ during the night, mainly due to alkene ozonolysis. In general, the nitrate radical had a negligible contribution during both the day and
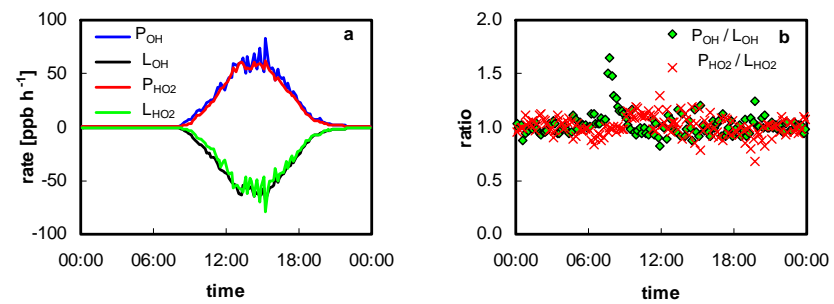

Fig. 3. (a) Production and destruction rates of $\mathrm{OH}$ and $\mathrm{HO}_{2}$. (b) Ratio of the rates of production to destruction of $\mathrm{OH}$ and $\mathrm{HO}_{2}$.

at night, which was mainly caused by the high NO concentrations during the campaign. The modelled $\mathrm{NO}_{3}$ concentrations showed two peaks of $1.0 \times 10^{6}$ molecules $\mathrm{cm}^{-3}$ at about $13 \mathrm{~h}$ and of $8.4 \times 10^{5}$ molecules $\mathrm{cm}^{-3}$ at $19 \mathrm{~h}$. The total number of the depleted molecules per day due to oxidation by $\mathrm{OH}, \mathrm{O}_{3}$ and $\mathrm{NO}_{3}$ were $6.4 \times 10^{12}, 7.4 \times 10^{11}$ and $2.0 \times 10^{10}$ molecules $\mathrm{cm}^{-3}$, respectively. Accordingly, the $\mathrm{OH}$ radical is the driving force of the oxidation capacity of the atmosphere in Santiago and thus, only the sources and sinks of the $\mathrm{OH}$ radical are further considered in this study.

\subsection{Radical production and destruction rates}

The total production and destruction rates of $\mathrm{OH}$ and $\mathrm{HO}_{2}$ calculated by the MCM model, constrained to campaign averaged data, are shown in Fig. 3a with the ratios of the radical production/destruction shown in Fig. 3b. The ratio was around unity throughout the day for the hydroperoxy radical whilst the ratio for the hydroxyl radical reaches a maximum of $\sim 1.7$ during the early morning, which may be caused by the photolysis of night time accumulated HONO.

The high total production and destruction rates are dominated by the recycling reactions of the peroxy radicals $\left(\mathrm{RO}_{2}+\mathrm{NO}\right.$ and $\left.\mathrm{HO}_{2}+\mathrm{NO}\right)$. The main loss of $\mathrm{RO}_{2}$ is due to its reaction with $\mathrm{NO}$ with an average daytime loss rate of $\sim 34.6 \mathrm{ppbvh}^{-1}$, which accounts for most of the $\mathrm{HO}_{2}$ production. The next most important $\mathrm{HO}_{2}$ sources are the reactions of $\mathrm{OH}$ with $\mathrm{CO}$ and $\mathrm{HCHO}$ with average daytime production rates of $\sim 0.5$ and $\sim 1.1 \mathrm{ppbv} \mathrm{h}^{-1}$, respectively. $\mathrm{HCHO}$ photolysis accounts for the $\mathrm{P}_{\mathrm{HO}_{2}}$ (prim) (see Sect. 2.3.1) with an average daytime production rate of $0.54 \mathrm{ppbv} \mathrm{h}^{-1}$ (Figs. $4 \mathrm{~b}$ and 5). In contrast to the other secondary oxygenated VOCs (OVOCs), HCHO is considered here as a net source of $\mathrm{HO}_{2}\left(\mathrm{P}_{\mathrm{HO}_{2}}\right.$ (prim)) since on average only $28 \%$ of the $\mathrm{HCHO}$ is formed photochemically (see Sect. 3.8.1). The main destruction route of $\mathrm{HO}_{2}$ is through its reaction with $\mathrm{NO}$ reaching rates up to $71 \mathrm{ppbv} \mathrm{h}^{-1}$, with a daytime average of $\sim 28.4 \mathrm{ppbv} \mathrm{h}^{-1}$ which corresponds to $\sim 90 \%$ of the total destruction rate, and is comparable to those of the TORCH, $299 \%$ (Emmerson et al., 2007) and BERLIOZ campaigns, $>80 \%$ (Mihelcic et al., 2003). The loss rates due to the $\mathrm{HO}_{2}$ self-reaction and its cross-reactions with $\mathrm{RO}_{2}$ are very small with daytime averages of $<0.01$ and 


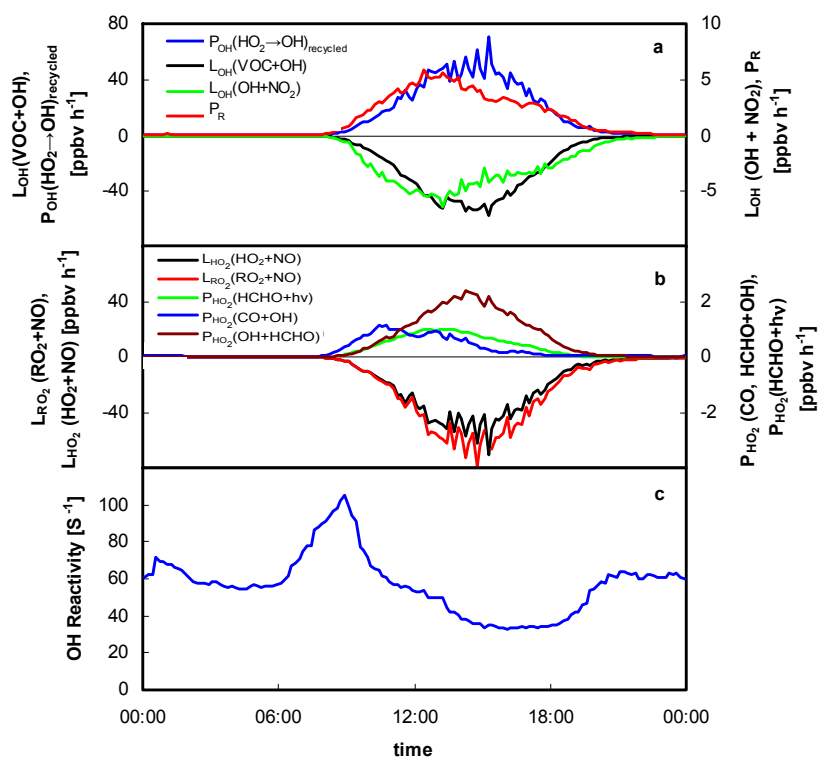

Fig. 4. Production and destruction rates of (a) $\mathrm{OH}$ and (b) $\mathrm{HO}_{2}$ and c) modelled $\mathrm{OH}$ reactivity.

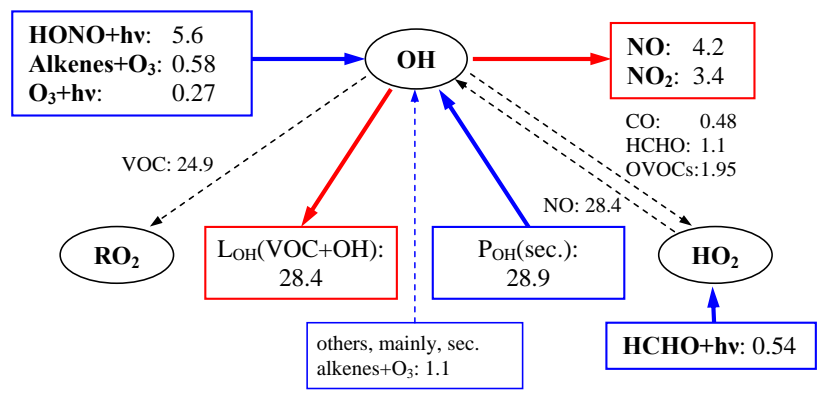

Fig. 5. Average daytime (08:00 $\mathrm{h}-19: 00 \mathrm{~h})$ fluxes of the net radical sources and sinks as calculated by the MCM model. Units are in $\mathrm{ppbv} \mathrm{h}^{-1}$. HONO net contribution $(\sim 52 \%)$ in this diagram is slightly lower than in the text because $[\mathrm{HONO}]_{\mathrm{PSS}}$ is calculated here using $[\mathrm{OH}]$ calculated by the MCM ( 4\% higher).

$0.02 \mathrm{ppbv} \mathrm{h}^{-1}$, respectively, in agreement with other urban studies (e.g., George et al., 1999; Ren et al., 2006). The main $\mathrm{OH}$ loss route is through its reaction with hydrocarbons, followed by reactions with $\mathrm{NO}$ and $\mathrm{NO}_{2}$. The rate of $\mathrm{OH}$ destruction due to hydrocarbon oxidation depends on the detailed chemical mechanism and can be estimated using the following relationships:

$\mathrm{L}_{\mathrm{OH}}(\mathrm{OH}+\mathrm{VOC}) \approx \mathrm{L}_{\mathrm{OH}}($ total $)-k_{\mathrm{NO}_{2}+\mathrm{OH}}\left[\mathrm{NO}_{2}\right]$

$[\mathrm{OH}]-k_{\mathrm{OH}+\mathrm{NO}}[\mathrm{NO}][\mathrm{OH}]$

or

$\mathrm{L}_{\mathrm{OH}}(\mathrm{OH}+\mathrm{VOC}) \approx \sum k_{\mathrm{i}}\left[\mathrm{VOC}_{\mathrm{i}}\right][\mathrm{OH}]$ where $\mathrm{L}_{\mathrm{OH}}$ (total) is the total loss rate as calculated by the MCM model and $k_{\mathrm{i}}$ represents the bimolecular rate constant for $\mathrm{OH}$ reaction with the corresponding VOC.

If Eq. (2) is used to calculate $\mathrm{L}_{\mathrm{OH}}$ due to reactions with the measured VOCs only, the $\mathrm{OH}$ loss rate will be underestimated since reactions with secondary VOC products are not included. Consequently, $\mathrm{HO}_{2}$ as a net source of $\mathrm{OH}$ will be over estimated. Relationship (1) takes into account the detailed degradation of the VOCs due to reactions with $\mathrm{OH}$, as calculated by the MCM photochemical box model, which includes the secondary VOC oxidation products. The average daytime (08:00 h-19:00 h) loss of $\mathrm{OH}$ radicals by VOC reaction calculated employing Eq. (2) is about $6 \mathrm{ppbv} \mathrm{h}^{-1}$ while that obtained using Eq. (1) is about $28.4 \mathrm{ppbv} \mathrm{h}^{-1}$, representing about $79 \%$ of the total $\mathrm{OH}$ loss. The fraction of $\mathrm{OH}$ loss by VOC reactions is similar to that calculated for Berlin, 5070\% (Mihelcic et al., 2003) and Mexico City, 72\% (Shirley et al., 2006).

$\mathrm{OH}$ production is dominated by the recycling reaction of $\mathrm{HO}_{2}$ with $\mathrm{NO}, \mathrm{P}_{\mathrm{OH}}\left(\mathrm{HO}_{2} \rightarrow \mathrm{OH}\right)_{\text {recycled, for which: }}$

$\mathrm{P}_{\mathrm{OH}}\left(\mathrm{HO}_{2} \rightarrow \mathrm{OH}\right)_{\text {recycled }}=\mathrm{P}_{\mathrm{OH}}\left(\mathrm{HO}_{2} \rightarrow \mathrm{OH}\right)-\mathrm{P}_{\mathrm{HO}_{2}}($ prim $)$,

where:

$\mathrm{P}_{\mathrm{OH}}\left(\left[\mathrm{HO}_{2} \rightarrow \mathrm{OH}\right)=k_{\mathrm{HO}_{2}+\mathrm{NO}}\left[\mathrm{HO}_{2}\right][\mathrm{NO}]\right.$.

$\mathrm{P}_{\mathrm{OH}}\left(\mathrm{HO}_{2} \rightarrow \mathrm{OH}\right)_{\text {recycled }}$ reached a maximum production rate of $70.5 \mathrm{ppbvh}^{-1}$ with a daytime average of $\sim 27.8$ ppbv h$^{-1}$ (Fig. 4a). The $\mathrm{P}_{\mathrm{OH}}\left(\mathrm{HO}_{2} \rightarrow \mathrm{OH}\right.$ ) route accounts for $\sim 80 \%$ of the total $\mathrm{OH}$ radical production. This value is comparable to that simulated during TORCH, $80 \%$ (Emmerson et al., 2007) and BERLIOZ, $>70 \%$ (Mihelcic et al., 2003) and Mexico City, >80\% (Shirley et al., 2006 and Sheehy et al., 2008). However, the oxidation of hydrocarbons results in the production of other radical precursors namely, $\mathrm{O}_{3}$ and $\mathrm{HCHO}$ as by-products in addition to alkene ozonolysis as a subsequent process. These processes, in addition to HONO photolysis, constitute the net radical production term, $\mathrm{P}_{\mathrm{R}}$ as shown in Fig. 4a. The rest of the $\mathrm{OH}$ production term $\left(1.1 \mathrm{ppbvh}^{-1}\right)$ is mainly due to the ozonolysis of the secondary alkenes produced from the oxidation process which are not constrained by the measurements (as illustrated in Fig. 5). The balance between $\mathrm{P}_{\mathrm{OH}}\left(\mathrm{HO}_{2} \rightarrow \mathrm{OH}\right)_{\text {recycled }}$ and $\mathrm{L}_{\mathrm{OH}}\left(\mathrm{OH}+\mathrm{VOC}\right.$ ) (see Sect. 3.5), results in the $\mathrm{NO}_{2}+\mathrm{OH}$ (termination) reaction becoming the net dominant sink for $\mathrm{OH}$ with a maximum loss rate of $6.4 \mathrm{ppbv} \mathrm{h}^{-1}$ and a daytime average loss rate of $\sim 3.4 \mathrm{ppbvh}^{-1}$ (see Fig. 5). An accompanying sensitivity analysis showed that only under very low $\mathrm{NO}_{\mathrm{x}}$ conditions reaching $<5 \%$ of the current levels $\mathrm{HO}_{2}$ recycling through its reaction with NO could be a limiting factor (Elshorbany et al., 2009). Under these conditions hydrocarbon oxidation could be a net sink for $\mathrm{OH}$ radicals, which in turn will also lead to a reduction in the $\mathrm{OH}$ sources, i.e. $\mathrm{O}_{3}$ and $\mathrm{HCHO}$ photolysis as well as alkenes ozonolysis. 


\subsection{OH reactivity}

The $\mathrm{OH}$ reactivity defined as the reciprocal of the $\mathrm{OH}$ radical lifetime has been calculated as $\mathrm{L}_{\mathrm{OH}}($ total $) /[\mathrm{OH}]$. The mean day average modelled $\mathrm{OH}$ reactivity is about $42 \mathrm{~s}^{-1}$ reaching a maximum of $105 \mathrm{~s}^{-1}$ during rush hour (Fig. 4c) and a night-time peak of $60 \mathrm{~s}^{-1}$. These numbers are slightly higher than the average and night-time peaks measured in Mexico City of 25 and $35 \mathrm{~s}^{-1}$, respectively, while the maximum measured $\mathrm{OH}$ reactivity in Mexico City of $120 \mathrm{~s}^{-1}$ exceeded that of Santiago (Shirley et al., 2006). Sheehy et al. (2008) have also reported a modelled total reactivity of $110 \mathrm{~s}^{-1}$ during the morning rush hour and 45-50 s $\mathrm{s}^{-1}$ at night in Mexico City. Both, Ren et al. (2006) and Yoshino et al. (2006) reported $\mathrm{OH}$ reactivities in the range of $10-100 \mathrm{~s}^{-1}$ in New York City and Tokyo, respectively. The diurnal variation of the modelled $\mathrm{OH}$ reactivity (Fig. 4c) is characterized by morning rush hour and night peaks in agreement with studies of Ren et al. (2006) and Shirley et al. (2006). Underestimation of the $\mathrm{OH}$ reactivity using relationship (2) has been previously observed when compared with measured $\mathrm{OH}$ reactivity in different field measurements (Di Carlo et al., 2004; Yoshino et al., 2006; Ren et al., 2006 and references therein). It is worth mentioning that the $\mathrm{OH}$ uptake on aerosol surfaces and the uncertainty of the rate coefficient of $\left(k_{\left(\mathrm{NO}_{2}+\mathrm{OH}\right)}\right)$ could not account for the missing $\mathrm{OH}$ reactivity in previous field measurements (Yoshino et al., 2006).

\subsection{Radical propagation}

Although hydrocarbon oxidation consumes most of the $\mathrm{OH}$ radicals $\left(\mathrm{L}_{\mathrm{OH}}(\mathrm{OH}+\mathrm{VOC})=28.4 \mathrm{ppbv} \mathrm{h}^{-1}\right.$ on average $)$, it also regenerates these radicals through the secondary production of $\mathrm{OH}, \mathrm{P}_{\mathrm{OH}}$ (sec.), (28.9 $\left.\mathrm{ppbvh}^{-1}\right)$ given by the sum of $\mathrm{P}_{\mathrm{OH}}\left(\mathrm{HO}_{2} \rightarrow \mathrm{OH}\right)_{\text {recycled }}\left(27.8 \mathrm{ppbv} \mathrm{h}^{-1}\right)$ and other secondary sources of $1.1 \mathrm{ppbv} \mathrm{h}^{-1}$ (mainly, secondary alkenes $+\mathrm{O}_{3}$, see Fig. 5). This result is in good agreement with the study of Emmerson et al. (2007) for which a similar balance was reported for stagnant "heatwave" periods during TORCH 2003, which were associated with high pollutant concentrations, low wind speed and high temperatures, which is probably similar to the situation in Santiago. On the contrary, for lower pollutant concentrations, $\mathrm{OH} \rightarrow \mathrm{RO}_{2}$ and $\mathrm{HO}_{2} \rightarrow \mathrm{OH}$ were not balanced (Emmerson et al., 2007).

While all the measured hydrocarbons were quantified, not all could be defined (see Sect. 3.1). In addition, not all defined hydrocarbons could be included in the MCM model because either some of these compounds were measured as a mixture of two compounds (or more) or not defined in the MCM (see Table 2). Thus, to further investigate the recycling process, an additional MCM model scenario has been run, in which the concentrations of all aromatic hydrocarbons and alkanes in addition to isoprene and propene have been increased by a factor of 2 while the rest of alkenes have been left unchanged. The reason for including only isoprene and
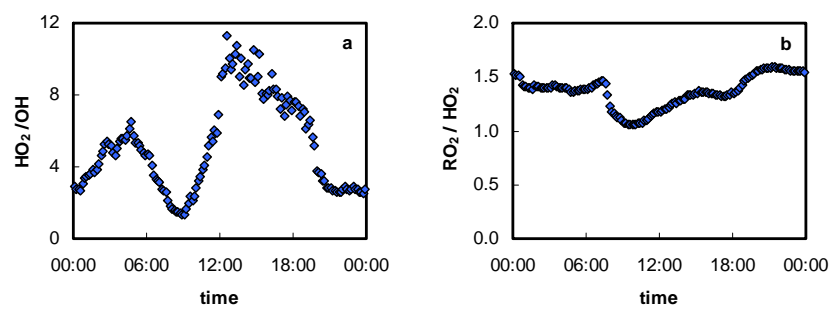

Fig. 6. Average MCM model diurnal variation of (a) $\mathrm{HO}_{2} / \mathrm{OH}$ ratio and (b) $\mathrm{RO}_{2} / \mathrm{HO}_{2}$ ratio.
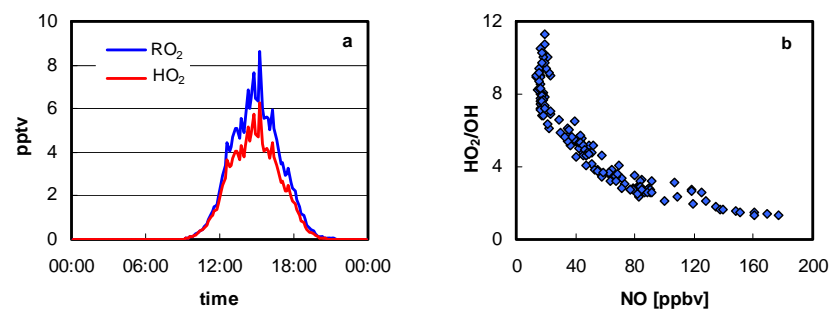

Fig. 7. (a): Average MCM model diurnal variation of $\mathrm{HO}_{2}$ and $\mathrm{RO}_{2}$. (b) $\mathrm{HO}_{2} / \mathrm{OH}$ ratio vs. NO.

propene is because of their relatively high reactivity with $\mathrm{OH}$ but their low potential for $\mathrm{OH}$ production through ozonolysis (see Sect. 3.8.2). Only $\sim 1 \%$ increase in the modelled $\mathrm{OH}$ concentration was observed for this additional scenario. In addition, although the fluxes $\mathrm{P}_{\mathrm{OH}}\left(\mathrm{HO}_{2} \rightarrow \mathrm{OH}\right)_{\text {recycled }}$ and $\mathrm{L}_{\mathrm{OH}}(\mathrm{OH}+\mathrm{VOC})$ increased by almost a factor of 2 , they were still balanced. These results clearly demonstrate that the main net radical sources and sinks were not affected by the VOC level and that the secondary radical sources (e.g. OVOC photolysis) and sinks (e.g. $\mathrm{RONO}_{2}$ ) are included in the recycling process, i.e. do not add to the net initiation sources or termination reactions. In the main, this can be explained by the high NO concentrations during daytime in Santiago and the fast recycling through the reactions $\mathrm{RO}_{2}+\mathrm{NO}$ and $\mathrm{HO}_{2}+\mathrm{NO}$.

The high recycling efficiency of the peroxy radicals can be demonstrated by the relatively low $\mathrm{HO}_{2} / \mathrm{OH}$ ratio evaluated by the MCM model (see Fig. 6a). The low maximum in the $\mathrm{HO}_{2} / \mathrm{OH}$ ratio of $\sim 11$ is typical for highly polluted conditions (e.g. Mihelcic et al., 2003) and implies a high recycling efficiency towards $\mathrm{OH}$. The $\mathrm{RO}_{2} / \mathrm{HO}_{2}$ ratio (Fig. 6b) of 1-1.5 is similar to that reported in Berlin with a maximum modelled ratio of 1.3 (Mihelcic et al., 2003) but much lower than that of 3.9 calculated for the TORCH campaign (Emmerson et al., 2007). While the $\mathrm{RO}_{2} / \mathrm{HO}_{2}$ and $\mathrm{HO}_{2} / \mathrm{OH}$ ratios both reach a minimum in the morning at about $09: 30 \mathrm{~h}$, the $\mathrm{HO}_{2} / \mathrm{OH}$ ratio reaches its afternoon maximum at about 14:30 $\mathrm{h}$ when the NO levels reach a minimum. The average daytime maximum $\mathrm{HO}_{2}$ radical concentration of 6.3 pptv (see Fig. 7a) is very similar to that measured in Tokyo, 2004 (Kanaya et al., 2007). The average daytime 

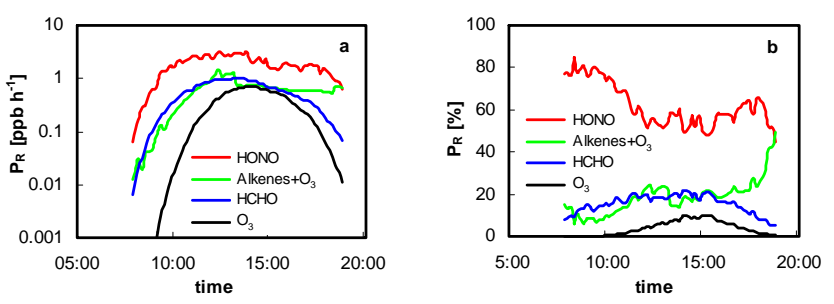

Fig. 8. Average absolute (a) and relative (b) diurnal daytime radical production rates $\left(\mathrm{P}_{\mathrm{R}}\right)$.

maximum total peroxy radical concentration of $15 \mathrm{pptv}$ is relatively low when compared with other studies (Mihelcic et al., 2003; Shirley et al., 2006) and can be explained by the high NO concentrations in the city of Santiago. This is also in agreement with the expected anti-correlation between the $\mathrm{HO}_{2} / \mathrm{OH}$ ratio and $\mathrm{NO}$ as shown in Fig. $7 \mathrm{~b}$ in agreement with other studies (e.g. Emmerson et al., 2007 and references therein).

\subsection{Net radical sources}

Evaluation of the total rates of radical initiation and termination required a simple steady state approach (see Sect. 2.3.1) that takes into account only the net radical sources and sinks. The net photolysis of HONO, HCHO, ozone and the reactions of ozone with alkenes are considered as initiation reactions while reaction of the $\mathrm{OH}$ radical with $\mathrm{NO}_{2}$ is the main termination reaction. According to this assumption, the radical production rates, $\mathrm{P}_{\mathrm{R}}$, of the main corresponding species were evaluated with the same rate constants used in MCMv3.1. The average absolute and relative diurnal contributions to radical production are shown in Fig. 8a and b respectively. For daytime conditions (08:00 h-19:00 h) HONO photolysis has by far the highest contribution of $\sim 55 \%$ followed by alkenes ozonolysis $(\sim 24 \%)$, HCHO photolysis $(\sim 16 \%)$ and ozone photolysis $(\sim 5 \%)$.

The high relative contribution of HONO is in excellent agreement with other recent studies (Ren et al., 2003, 2006; Kleffmann et al., 2005; Acker et al., 2006 a, b), in which an integrated contribution of up to $56 \%$ was reported. For average daytime conditions (08:00 h-19:00 h), high net mean and maximum $\mathrm{OH}$ production rates by $\mathrm{HONO}$ photolysis of $1.7 \mathrm{ppbv}^{-1}$ and $3.1 \mathrm{ppbvh}^{-1}$, respectively, have been determined, the latter being even higher than the $\sim 2 \mathrm{ppbv} \mathrm{h}^{-1}$ reported by Ren et al. (2003) for New York City. Only in the study of Acker et al. (2006b) was a higher maximum $\mathrm{OH}$ production rate by HONO photolysis of up to $6 \mathrm{ppbvh}^{-1}$ reported for the city of Rome. However, this number is an upper limit since in their estimations the back reaction of $\mathrm{NO}+\mathrm{OH}$ was not considered. During the morning, for which the maximum production rate was reported by Acker et al. (2006 b), high NO concentrations can especially lead to a strong overestimation of net $\mathrm{OH}$ production rates (see Sect. 3.8.3). On a 24-h basis, HONO photolysis was also the dominant radical source contributing $\sim 52 \%$ to $\mathrm{P}_{\mathrm{R}}$ followed by alkene ozonolysis, $\sim 29 \%$, HCHO photolysis $\sim 15 \%$ and ozone photolysis $\sim 4 \%$. During almost the entire daytime the HONO photolysis contribution was higher than any other primary source except in the early evening when the contribution from alkene ozonolysis starts to dominate. This is caused by the decreasing light intensity with the ozone concentrations remaining high. In the early morning, the photolysis of HONO is the dominant source representing $\sim 80 \%$ of the total radical budget. This is due to its low dissociation energy threshold and the high concentrations accumulated during night-time.

A high morning peak production rate that slows down during the day has been previously observed in Los Angeles, Milan, Pabstthum (downwind of Berlin) and Mexico City (George et al., 1999; Alicke et al., 2002, 2003; Volkamer et al., 2007, respectively). However, in contrast to these studies, where the net $\mathrm{OH}$ production was very low in the afternoon, the relative contribution of the $\mathrm{OH}$ production by HONO photolysis never falls below $40 \%$ for Santiago (see Fig. 8b). This high daytime contribution of HONO is in good agreement with other recent studies under urban conditions (Ren et al., 2003; Acker et al., 2006b). The reason for the difference between the two sets of studies in which the contribution of HONO to afternoon radical production is either significant or negligible is still unclear. One potential explanation would be an overestimation of HONO due to interferences and sampling artefacts for all studies, in which wet chemical instruments were used (see Kleffmann and Wiesen, 2008). However, the LOPAP instrument used in the present study corrects for interferences and was successfully validated against the DOAS technique in a recent urban study in Milan (Kleffmann et al., 2006). In addition, a simple PSS analysis of the HONO data from the Milan campaign showed that $\mathrm{HONO}$ was also a strong net source of $\mathrm{OH}$ radicals during daytime, a result confirmed by the parallel co-located DOAS measurements (Kleffmann et al., 2006). This result is in contradiction to other DOAS measurements carried out at the same place under similar meteorological conditions and time of the year (Alicke et al., 2002). The reason for this difference is still unclear. Another explanation for the different daytime contributions of HONO in different studies may be the different sampling altitudes and strong vertical gradients during daytime. However, in the study of Alicke et al. (2002) the light path of the DOAS was even lower than the sampling height during the present study and no gradients were observed during daytime (Stutz et al., 2002). In addition, in the present study no horizontal gradients were observed towards the wall of the building on which the external sampling unit was fixed, excluding strong local wall sources. In conclusion, the reason for the different daytime contribution of $\mathrm{HONO}$ to the $\mathrm{OH}$ production in different studies remains unclear. The high contribution of HONO observed in the present study may be explained by the unique geographical situation of Santiago under very high pollution levels. 


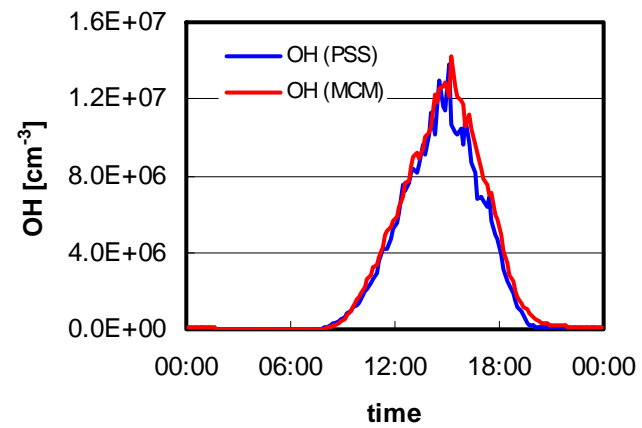

Fig. 9. Average diurnal variation of $\mathrm{OH}$ concentration calculated by both the MCM and PSS.
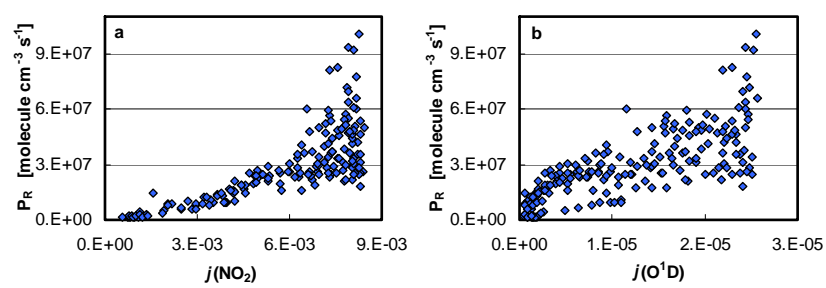

Fig. 10. Correlations between the radical production rate, $P_{R}$ and (a) $j\left(\mathrm{NO}_{2}\right)$ and (b) $j\left(\mathrm{O}^{1} \mathrm{D}\right)$.

The average diurnal variation of the $\mathrm{OH}$ concentration calculated by both the MCM and PSS models are shown in Fig. 9. The maximum estimated $\mathrm{OH}$ concentrations of $1.4 \times 10^{7}$ molecules $\mathrm{cm}^{-3}$ occurs approximately one hour after the maximum in $j\left(\mathrm{O}^{1} \mathrm{D}\right)$. Using different simplified photo-stationary state approaches, Rappenglück et al. (2000) and Rubio et al. (2005) estimated much lower values of $\sim 2.6 \times 10^{6}$ and $\sim 8.8 \times 10^{6}$ molecules $\mathrm{cm}^{-3}$, respectively. Possible reasons for these differences are that Rappenglück et al. (2000) did not consider HONO photolysis and alkenes ozonolysis while Rubio et al. (2005) did not consider alkenes ozonolysis.

The excellent agreement between the $\mathrm{OH}$ concentration profiles evaluated by both the MCM and PSS models shows that the major $\mathrm{OH}$ radical sources and sinks are included in the PSS model and that the sinks $\mathrm{OH} \rightarrow \mathrm{RO}_{2}$ are balanced with the sources $\mathrm{RO}_{2} \rightarrow \mathrm{OH}$.

\subsection{Correlation of $\mathrm{OH}$ with $\mathbf{j}\left(\mathrm{O}^{1} \mathrm{D}\right)$ and $\mathbf{j}\left(\mathrm{NO}_{2}\right)$}

In spite of the complexity of the mechanisms controlling $\mathrm{OH}$ concentrations, the $\mathrm{OH}$ correlation with $j\left(\mathrm{O}^{1} \mathrm{D}\right)$ has shown to have a linear pattern in both urban and rural environments and for long and short time periods (Rohrer et al., 2006, Kanaya et al., 2007). For Santiago, the calculated $\mathrm{OH}$ radical concentration also correlates well with $j\left(\mathrm{O}^{1} \mathrm{D}\right)$ $\left(R^{2}=0.54\right)$, and $j\left(\mathrm{NO}_{2}\right)\left(R^{2}=0.56\right)$. An even stronger correlation between the measured daytime $\mathrm{OH}$ and $j\left(\mathrm{NO}_{2}\right)$ has been obtained in other studies (e.g. Kanaya et al., 2007 and
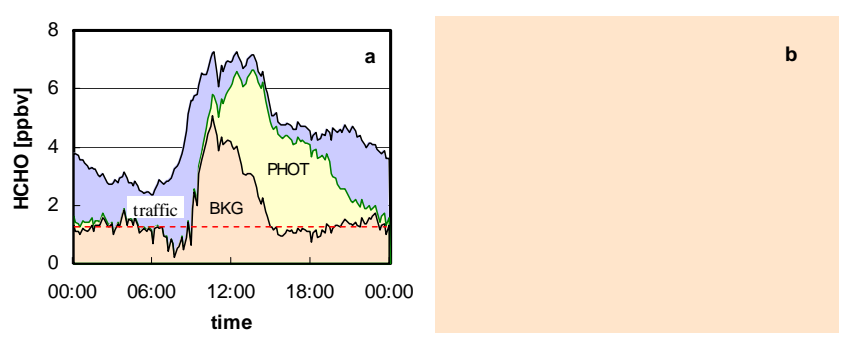

Fig. 11. (a) HCHO source apportionment, (b) Photochemical $\mathrm{HCHO}$ simulated with MCM and calculated with $\mathrm{O}_{3}$ tracer.

references therein). In addition, a better correlation between the total rate of radical initiation, $\mathrm{P}_{\mathrm{R}}$, and $j\left(\mathrm{NO}_{2}\right)$ compared to the correlation with $j\left(\mathrm{O}^{1} \mathrm{D}\right)$ was observed in the present study, especially for low $j$-values in the morning and evening (see Fig. 10a and b). This can be explained by the much broader diurnal profile of $j\left(\mathrm{NO}_{2}\right)$ compared to $j\left(\mathrm{O}^{1} \mathrm{D}\right)$. The results demonstrate the importance of the UV-A rather than UV-B region for the production of $\mathrm{OH}$ during daytime which is dominated by the daytime production of HONO.

\subsection{Source apportionments of the main $\mathrm{OH}$ radical pre- cursors}

\subsubsection{Formaldehyde (HCHO) contribution}

$\mathrm{HCHO}$ is a main photochemical oxidation precursor contributing $\sim 16 \%$ of the total primary radical sources, $\mathrm{P}_{\mathrm{R}}$, during the daytime in Santiago. HCHO is both primarily emitted and produced photochemically from the oxidation of VOCs (Friedfeld et al., 2002; Garcia et al., 2006). In this study, we have used $\mathrm{O}_{3}$ and $\mathrm{NO}_{\mathrm{x}}$ as $\mathrm{HCHO}$ tracers for which $\mathrm{NO}_{\mathrm{x}}$ has been assumed as an indicator for primary $\mathrm{HCHO}$ resulting from direct emissions and $\mathrm{O}_{3}$ as a photochemical indicator. The measured $\mathrm{HCHO}$ was described by:

$[\mathrm{HCHO}]_{\text {measured }}=\beta_{o}+\beta_{1} \times\left[\mathrm{O}_{3}\right]+\beta_{2} \times\left[\mathrm{NO}_{\mathrm{x}}\right]$

where $\beta_{o}$ is the background $\mathrm{HCHO}(\mathrm{BKG})$, which stands here for the residual fraction of HCHO that can not be accounted as photochemical or primary, and the factors $\beta_{1}$ and $\beta_{2}$ are the average weighted slopes of $\mathrm{HCHO}$ to $\mathrm{O}_{3}$ and $\mathrm{NO}_{\mathrm{x}}$, respectively. For the whole campaign, values of $\beta_{1}=0.062$ and $\beta_{2}=0.018 \mathrm{ppbv} / \mathrm{ppbv}$, respectively were determined. The photochemically formed HCHO (PHOT) comprises up to $>70 \%$ of the observed HCHO in the afternoon (Fig. 11a). In contrast, during the early morning rush hour the primary HCHO (traffic) comprised up to $90 \%$ (Fig. 11a). Averaged on a daily basis, $\sim 34 \%$ of the measured $\mathrm{HCHO}$ is due to direct emissions while photochemical and background $\mathrm{HCHO}$ account for $\sim 28$ and $\sim 38 \%$, respectively. The value of the direct emitted fraction is very similar to the $32 \pm 16 \%$ previously reported by Rubio et al. (2006) while the sum of 
the photochemical and background fractions is similar to the secondary fraction reported during the summer in Santiago, 79 $\pm 23 \%$ (Rubio et al., 2006) and London, 74\% (Harrison et al., 2006). Since only $28 \%$ of the HCHO is photochemically formed as a result of hydrocarbon oxidation, $\mathrm{HCHO}$ was considered as a net source of $\mathrm{HO}_{2}\left(\mathrm{P}_{\mathrm{HO}_{2}}(\right.$ prim) $)$ in the present study.

Photochemical HCHO production has also been simulated using the MCMv3.1 photochemical box model constrained with all measured trace gases including the NMHCs except the measured HCHO. The photochemical HCHO calculated using $\mathrm{O}_{3}$ as tracer matched well that calculated by the MCM model with a gap in the late afternoon (see Fig. 11b). This gap however, is due to the afternoon ozone shoulder, which has become a typical feature during photochemical smog episodes in Santiago de Chile (Rappenglück, 2000, 2005). Primary HCHO starts to build up in the early morning at about $06: 30 \mathrm{~h}$, nearly one hour before sunrise, and becomes the dominant source until $\sim 09: 00 \mathrm{~h}$. The photochemical formation of $\mathrm{HCHO}$ follows the light intensity, and starts to increase nearly an hour after the sunrise, becoming dominant at around $\sim 13: 00 \mathrm{~h}$ and reaching a maximum at $\sim 16: 00 \mathrm{~h}$ nearly $3 \mathrm{~h}$ after the maximum in $j\left(\mathrm{NO}_{2}\right)$. The photochemical HCHO contribution starts to decline at $\sim 19: 00 \mathrm{~h}$, about $3 \mathrm{~h}$ after the $j\left(\mathrm{NO}_{2}\right)$ starts decreasing, while the primary $\mathrm{HCHO}$ turns again to be the dominant source until 02:00 h due to night time emissions. The average background baseline of $\mathrm{HCHO}$ is less than 2 ppbv representing about $20 \%$ of the total HCHO throughout the day (red dotted line in Fig. 11a). The baseline of the background determines the average $\mathrm{HCHO}$ background values during the early morning and afternoon and is in agreement with other studies (Garcia et al., 2006). However, unpredicted high background concentrations of $\mathrm{HCHO}$, reaching a maximum of up to $5 \mathrm{ppbv}$ at $\sim 10: 00 \mathrm{~h}$, have been evaluated. One explanation is an underestimation of photochemical produced $\mathrm{HCHO}$ by the use of $\mathrm{O}_{3}$ as tracer, since photochemically produced $\mathrm{O}_{3}$ is first efficiently titrated by the morning rush-hour NO. In this case, photochemical HCHO would become even more important after $\sim 09: 00 \mathrm{~h}$. The use of $\mathrm{O}_{\mathrm{x}}\left(\mathrm{O}_{3}+\mathrm{NO}_{2}\right)$ as tracer was not possible, since $\mathrm{NO}_{2}$ is also linked to direct emissions (Carslaw and Beevers, 2005). Another explanation for the high HCHO background peak may be direct HCHO emissions that are not traced by $\mathrm{NO}_{\mathrm{x}}$ (Garcia et al., 2006). These emissions should then however, be limited to the time period 09:00 h-14:00 h (see Fig. 11a), which is unreasonable. Finally, the high background HCHO could also be caused by mixing of surface air masses with the residual layer in the morning when the boundary layer height is increasing. The concentration of $\mathrm{HCHO}$ in the residual layer could remain high from the previous day. Rappenglück et al. (2005) has also observed a similar background carbonyl peak at noontime in Santiago.
The contribution of each of the VOC classes (alkenes, alkanes, aromatics) to the photochemically formed formaldehyde has been determined by the MCM model. As expected, the alkenes are the dominant photochemical precursor contributing alone more than $70 \%$, followed by aromatics, $18 \%$, and alkanes, $12 \%$. These contributions are in good agreement with those reported in Mexico City (Volkamer et al., 2007). Of the alkenes, oxidation of isoprene contributes alone about $23 \%$ to the photochemical produced HCHO, propene $11 \%$ and $\alpha$-pinene $9 \%$. From the aromatics class, 1,3,5-trimethylbenzene represents $6 \%$ followed by orthoxylene, $4 \%$, and toluene, $3 \%$. Of the alkanes, 2-metylbutane, decane and 3-methylpentane are the major sources contributing to about $3 \%, 2 \%$ and $1.6 \%$ respectively. $\mathrm{OH}$ is the dominant oxidant responsible for nearly $85 \%$ of the total $\mathrm{HCHO}$ produced by the oxidation of hydrocarbons followed by alkene ozonolysis, $14 \%$. The contribution of $\mathrm{NO}_{3}$ was found to be negligible.

\subsubsection{Alkene ozonolysis contribution}

Unlike the other $\mathrm{OH}$ radical sources, alkene ozonolysis can occur at night as well as during the day (Paulson and Orlando, 1996; Johnson and Marston, 2008). In this study, the ozonolysis of alkenes was found to be the second most important radical initiation source after HONO photolysis, accounting for $29 \%$ of the $\mathrm{OH}$ formed on 24-h basis. Although their total concentrations are only $\sim 19 \%$ of the total measured alkenes, internal alkenes contribute $86 \%$ to the total alkene $\mathrm{OH}$ radical production, $\mathrm{P}_{\mathrm{OH}}$ (alkenes) given by $\Sigma k_{\mathrm{O}_{3}+\text { alkene }}$ [alkene][O $\left.\mathrm{O}_{3}\right] \Phi_{\mathrm{OH}}$ (see Sect. 2.3.1), and nearly $21 \%$ to the total primary radical production, $\mathrm{P}_{\mathrm{R}}$, as shown in Fig. 12a. The order of efficiency in $\mathrm{OH}$ production from the reactions of ozone with alkenes is:

internalalkenes $>$ cycloalkenes $>$ terminalalkenes.

Among the internal alkenes, 2-methyl-2-butene and 2,3dimethyl-2-butene have the highest contributions to $\mathrm{P}_{\mathrm{OH}}$ (alkenes) with $37 \%$ and 33\%, respectively (see Fig. 12b). Cycloalkenes are represented by $\alpha$-pinene alone and contribute about $6.6 \%$ to the total alkene concentration, $\sim 9 \%$ to total alkene $\mathrm{OH}$ production and $\sim 2 \%$ to $\mathrm{P}_{\mathrm{R}}$. The other measured cycloalkenes are not yet included in the MCM. Terminal alkenes, while representing $75 \%$ of the alkenes concentration, contribute only $\sim 5 \%$ to the total alkene $\mathrm{OH}$ production rate and about $1 \%$ to $P_{R}$ (Fig. 12a).

\subsubsection{Contribution of HONO during daytime}

As already discussed, over the last few years it has been demonstrated that the contribution of nitrous acid to the primary radical production, $P_{R}$, has been frequently underestimated (e.g. Ren et al., 2003; Kleffmann et al., 2005; Acker et al., 2006a). High measured daytime concentrations point to an additional strong HONO source (Kleffmann, 2007), for 

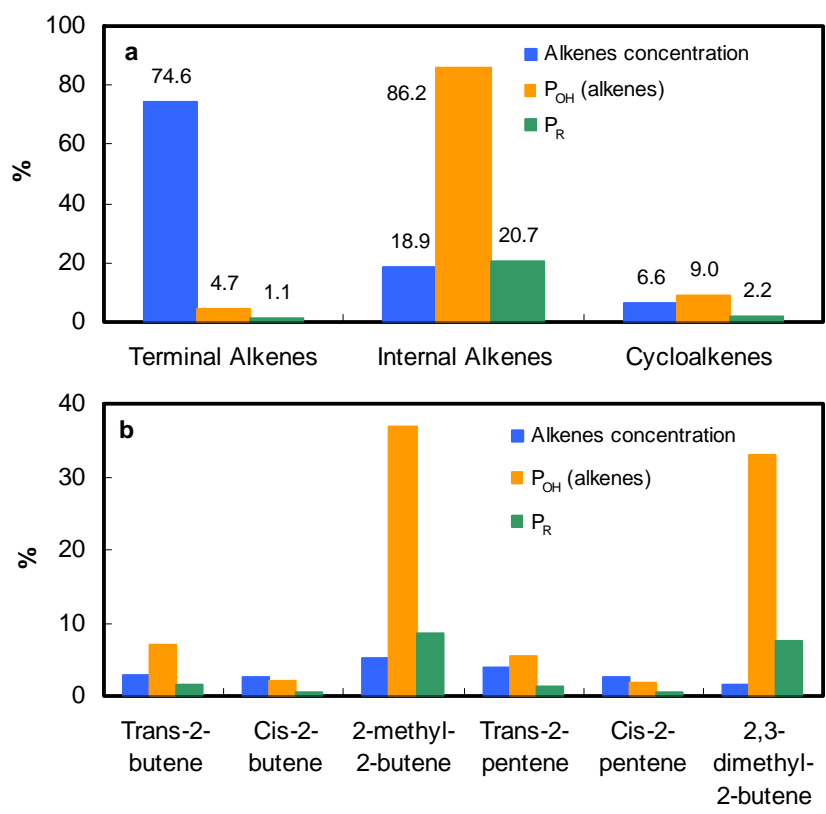

Fig. 12. Contributions of (a) different alkenes and (b) internal alkenes to the $\mathrm{OH}$.

which several photochemical reactions have recently been proposed from laboratory studies (Zhou et al., 2003; George et al., 2005; Bejan et al., 2006; Stemmler et al., 2006, 2007).

The photostationary state concentration of HONO, $[\mathrm{HONO}]_{\mathrm{PSS}}$, was calculated from the known gas phase chemistry by the following equation:

\section{$[\mathrm{HONO}]_{\mathrm{PSS}}=k_{\mathrm{OH}+\mathrm{NO}}[\mathrm{OH}][\mathrm{NO}] /(j(\mathrm{HONO})$ $\left.+k_{\mathrm{OH}+\mathrm{HONO}}[\mathrm{OH}]\right)$.}

On average, [HONO $]_{\text {PSS }}$ was found to account for about $69 \%$ of the observed HONO concentration reaching its maximum contribution during the rush hour peak time at $\sim 10: 00 \mathrm{~h}$ coinciding with the NO peak. During the early afternoon (12:30 $\mathrm{h}-15: 00 \mathrm{~h})$, when the absolute production rate of $\mathrm{OH}$ by HONO photolysis was highest, the PSS contributed on average $\sim 66 \%$ of the measured HONO. Thus, one reason for the extreme high HONO daytime concentrations observed is the daytime production of HONO by the gas phase reaction of $\mathrm{NO}+\mathrm{OH}$ caused by the very high levels of $\mathrm{OH}$ and $\mathrm{NO}$. However, this reaction and the uncertainty in the PSS concentration by only gas phase chemistry (see below) cannot explain the measured daytime values of $\mathrm{HONO}$ alone. If the heterogeneous dark conversion of $\mathrm{NO}_{2}$ (see Sect. 3.8.4) is included, the PSS increases by only $4 \%$ during noon, thus, an additional daytime source of HONO is needed. The most important uncertainty in the calculation of the PSS concentration besides the measured [NO], [HONO] and $j(\mathrm{HONO})$ values is modelled $[\mathrm{OH}]$. However, an average maximum $\mathrm{OH}$ concentrations of $2.2 \times 10^{7}$ molecules $\mathrm{cm}^{-3}$, which is about
$155 \%$ of the modelled $\mathrm{OH}$, is required to get [HONO$]_{\mathrm{PSS}}$ equal to measured values. The $\mathrm{OH}$ simulated by the MCM model was validated through different field intercomparisons and showed excellent agreement with that measured, especially under such high $\mathrm{NO}_{\mathrm{x}}$ conditions (Mihelcic et al., 2003; Sheehy et al., 2008). Recently, Sheehy et al. (2008) reported maximum $\mathrm{OH}$ over prediction by the MCM of $20 \%$ during afternoon. In contrast, for Santiago an under prediction of the modelled $\mathrm{OH}$ level by $\sim 55 \%$ would be necessary to explain the daytime concentrations of HONO. Therefore, additional average daytime HONO sources of $1.7 \mathrm{ppbv} \mathrm{h}^{-1}$ are necessary. These additional daytime HONO sources become obvious from the diurnal variation of the $\mathrm{HONO} / \mathrm{NO}_{\mathrm{x}}$ ratio (Fig. 2 b). While the night-time behaviour, with a linear increase of the $\mathrm{HONO} / \mathrm{NO}_{\mathrm{x}}$ ratio from $2-5 \%$, is typical for urban conditions and can be explained by known emission and heterogeneous conversion of $\mathrm{NO}_{2}$ on ground surfaces (Alicke et al., 2002; Kleffmann et al., 2002, 2003; Vogel et al., 2003), the second daytime maximum, reaching almost $8 \%$, has not been observed in our previous urban studies in such a pronounced manner. A daytime maximum under urban conditions was however observed for the city of Rome (Acker et al, 2006b) and is also typical for remote and mountain site measurements (see e.g., Huang et al., 2002; Kleffmann et al., 2002; Acker et al., 2006a, Kleffmann and Wiesen, 2008). A daytime maximum in the $\mathrm{HONO} / \mathrm{NO}_{\mathrm{x}}$ ratio can only be explained by a very strong additional photochemical HONO source. Three photochemical mechanisms were identified recently, two of them being well correlated to $j\left(\mathrm{NO}_{2}\right)$ (George et al., 2005; Bejan et al., 2006; Stemmler et al., 2006, 2007), while the photolysis of nitric acid (Zhou et al., 2003) would better correlate to $j\left(\mathrm{O}^{1} \mathrm{D}\right)$, caused by the much lower wavelength range of the nitric acid photolysis. This was tested by plotting the campaign averaged net production rate of $\mathrm{OH}$ radicals due to $\mathrm{HONO}$ photolysis against $j\left(\mathrm{NO}_{2}\right)$ and $j\left(\mathrm{O}^{1} \mathrm{D}\right)$. Both plots $\left(j\left(\mathrm{NO}_{2}\right), R^{2}=0.62\right.$ and $\left.j\left(\mathrm{O}^{1} \mathrm{D}\right), R^{2}=0.45\right)$ show that the daytime source is correlated with the light intensity, confirming former assumptions of a photochemical production of HONO. However, since a better correlation was obtained when $j\left(\mathrm{NO}_{2}\right)$ was used, especially for low $j$-values, the heterogeneous conversion of $\mathrm{NO}_{2}$ on photosensitized organics (George et al., 2005; Stemmler et al., 2006, 2007) and gas phase photolysis of organic nitrogen compounds (e.g. nitrophenols, Bejan et al., 2006) may be of higher importance compared to the nitric acid photolysis in Santiago. Similar results were obtained when plotting $\mathrm{P}_{\mathrm{R}}$ against $j\left(\mathrm{NO}_{2}\right)$ and $j\left(\mathrm{O}^{1} \mathrm{D}\right)$ (see Fig. 10 and Sect. 3.7).

\subsubsection{HONO dark sources}

Besides photochemical daytime sources of HONO, formation of HONO during the night by heterogeneous conversion of $\mathrm{NO}_{2}$ on humid surfaces is well known (Alicke et al., 2002). The dark heterogeneous rate constant of HONO formation, $k_{\text {het }}$, due to the first order conversion of 
$\mathrm{NO}_{2}$ on humid surfaces $\left(\mathrm{NO}_{2}+\mathrm{X} \rightarrow \mathrm{HONO}\right)$ has been estimated from the increase of the $\mathrm{HONO} / \mathrm{NO}_{2}$ ratio during the night (see also Alicke et al., 2002). An average $k_{\text {het }}$ of $(3.5 \pm 1.9) \times 10^{-6} \mathrm{~s}^{-1}$ has been obtained, which is similar to that of $(3.3 \pm 1.4) \times 10^{-6} \mathrm{~s}^{-1}$ obtained by Alicke et al. (2002). This heterogeneous rate constant has been found to correlate inversely with the wind speed $\left(R^{2}=0.65\right)$ confirming heterogeneous formation on ground surfaces during the night (Kleffmann et al., 2003). However, almost no correlation of $k_{\text {het }}$ with relative humidity was observed $\left(R^{2}=0.086\right)$ in contrast to the study by Stutz et al. (2004). The lack of water dependence can be explained by the heterogeneous conversion of $\mathrm{NO}_{2}$ into HONO on adsorbed organics (Arens et al., 2002; Gutzwiller et al. 2002; Ammann et al., 2005), which are persistent on any urban surface. For this type of reaction only a moderate humidity dependence was observed in the laboratory (Arens et al., 2002) for a humidity range comparable to the present study. In addition, $\mathrm{NO}_{2}$ conversion on organic surfaces is much faster than the typical proposed reaction of $\mathrm{NO}_{2}$ with water on surfaces (Finlayson-Pitts et al., 2003) at atmospheric $\mathrm{NO}_{2}$ levels and thus is a more reasonable source for night-time formation of $\mathrm{HONO}$ in the atmosphere.

\section{Conclusion}

The oxidising capacity of the atmosphere over the urban area of Santiago, Chile, has been studied for the first time during an extensive measurement campaign in the summer 2005. A zero dimensional photochemical box model containing the detailed gas phase mechanism MCMv3.1 was constrained with a suite of ancillary measurements including $\mathrm{HONO}, \mathrm{HCHO}, \mathrm{O}_{3}, \mathrm{NO}_{\mathrm{x}}, \mathrm{PAN}, \mathrm{VOCs}, j\left(\mathrm{O}^{1} \mathrm{D}\right), j\left(\mathrm{NO}_{2}\right)$ and meteorological parameters. The average ratio of total production/destruction rates of the hydroperoxy radical $\left(\mathrm{HO}_{2}\right)$ was around unity throughout the day, whilst the production/destruction ratio for the hydroxyl radical $(\mathrm{OH})$ reaches a maximum of $\sim 1.7$ during the morning. $\mathrm{HO}_{2}$ radical production was dominated by the $\mathrm{RO}_{2}+\mathrm{NO}$ reaction while $\mathrm{HO}_{2}$ destruction was dominated by its reaction with $\mathrm{NO}$, which was also the strongest $\mathrm{OH}$ source $(\sim 80 \%)$. OH loss was dominated with its reaction with hydrocarbons $(\sim 79 \%)$. The high recycling efficiency was demonstrated by the low $\mathrm{HO}_{2} / \mathrm{OH}$ ratio of $\sim 11$. The $\mathrm{RO}_{2} / \mathrm{HO}_{2}$ ratio of $1-1.5$ is comparable to that of other urban studies. Both, the MCM and simple PSS models predict the same $\mathrm{OH}$ concentrations showing that the main radical precursors included in the PSS model are dominant and that the $\mathrm{OH} \rightarrow \mathrm{RO}_{2}$ sinks are balanced by the $\mathrm{RO}_{2} \rightarrow \mathrm{OH}$ sources. This balance was verified by an additional MCM model scenario that was run under a different VOC reactivity regime. The high modelled $\mathrm{OH}$ concentrations show that the high daytime concentrations of HONO cannot be explained by known gas phase chemistry and suggest the presence of an additional strong daytime source of HONO. This conclusion is further supported by the observa- tions of a second daytime maximum in the $\mathrm{HONO} / \mathrm{NO}_{\mathrm{x}}$ ratio. $\mathrm{HONO}$ was the most important direct $\mathrm{OH}$ source with daytime average contribution of 55\% followed by alkenes ozonolysis, $24 \%$, $\mathrm{HCHO}$ photolysis, $16 \%$, and $\mathrm{O}_{3}$ photolysis, $5 \%$. The better correlation of the daytime HONO source with $j\left(\mathrm{NO}_{2}\right)$ compared to $j\left(\mathrm{O}^{1} \mathrm{D}\right)$ shows that daytime HONO formation cannot be explained by the recently proposed nitric acid photolysis channel. Alkene ozonolysis represented the second most important direct source of $\mathrm{OH}$ radicals with internal alkenes contributing $\sim 86 \%$ to the $\mathrm{OH}$ radical formation. HCHO source apportionment has been achieved using $\mathrm{NO}_{\mathrm{x}}$ and $\mathrm{O}_{3}$ as direct emission and photochemical tracers, respectively. Photochemical HCHO comprises up to $>70 \%$ of the observed $\mathrm{HCHO}$ during the afternoon. The HCHO photochemical source apportionment has revealed that alkenes contribute most by $70 \%$ followed by aromatics, $18 \%$, and alkanes, $12 \%$. The major contribution of $\mathrm{HONO}$ to the direct $\mathrm{OH}$ radical production is in good agreement with several recent studies and highlights the importance of HONO measurements in studies which focus on the radical chemistry of the atmosphere.

Acknowledgements. Financial support by the German Academic Exchange Service (DAAD) under contract no. ale-03/23601 and FONDECYT (Project 1040032 and 1085007) is gratefully acknowledged. Y. Elshorbany would like to thank Roberto Sommariva, Earth System Research laboratory, NOAA, Boulder, US for supplying the python scripts used for the ROPA calculations. We also would like to thank Birger Bohn, Forschungszentrum Jülich, Germany for the calibration of the $j\left(\mathrm{NO}_{2}\right)$ filter radiometer. Thanks are given to the Physics Department, Faculty of Science, $\mathrm{USACH}$, for the use of their facilities during the field campaign.

Edited by: A. Hofzumahaus

\section{References}

Acker, K., Möller, D., Wieprecht, W., Meixner, F. X., Bohn, B., Gilge, S., Plass-Dülmer, C., and Berresheim, H.: Strong Daytime Production of $\mathrm{OH}$ from $\mathrm{HNO}_{2}$ at a Rural Mountain Site, Geophys. Res. Lett., 33, L02809, doi:10.1029/2005GL024643, 2006 .

Acker, K., Febo, A., Trick, S., Perrino, C., Bruno, P., Wiesen, P., Möller, D., Wieprecht, W., Auel, R., Guisto, M., Geyer, A., Platt, U., and Allegrini, I.: Nitrous Acid in the Urban Area of Rome, Atmos. Environ., 40, 3123-3133, $2006 \mathrm{~b}$.

Alicke, B., Platt, U., and Stutz, J.: Impact of nitrous acid photolysis on the total hydroxyl radical budget during the Limitation of Oxidant Production/Pianura Padana Produzione di Ozono study in Milan, J. Geophys. Res., 107(D22), 8196, doi:10.1029/2000JD000075, 2002.

Alicke, B., Geyer, A., Hofzumahaus, A., Holland, F., Konrad, S., Pätz, H. W., Schäfer, J., Stutz, J., Volz-Thomas, A., and Platt, U.: $\mathrm{OH}$ formation by HONO photolysis during the BERLIOZ experiment, J. Geophys. Res. 108(D4), 8247, doi:10.1029/2001JD000579, 2003. 
Ammann, M., Rössler, E., Strekowski, R., and George, C.: Nitrogen Dioxide Multiphase Chemistry: Uptake Kinetics on Aqueous Solutions Containing Phenolic Compounds, Phys. Chem. Chem. Phys., 7, 2513-2518, 2005.

Appel, B. R., Winer, A. M., Tokiwa, Y., and Biermann, H. W.: Comparison of Atmospheric Nitrous Acid Measurements by Annular Denuder and Optical Absorption Systems, Atmos. Environ., 24 A, 611-616, 1990.

Arens, F., Gutzwiller, L., Gäggeler, H. W., and Ammann, M.: The Reaction of $\mathrm{NO}_{2}$ with Solid Anthrarobin (1,2,10-trihydroxyanthracene), Phys. Chem. Chem. Phys. 4, 3684-3690, 2002.

Bejan, I., Abd El Aal, Y., Barnes, I., Benter, T., Bohn, B., Wiesen, P., and Kleffmann J.: The Photolysis of Ortho-Nitrophenols: A new Gas Phase Source of HONO, Phys. Chem. Chem. Phys., 8, 2028-2035, 2006.

Bloss, C., Wagner, V., Bonzanini, A., Jenkin, M. E., Wirtz, K., Martin-Reiejo, M., and Pilling, M. J.: Evaluation of detailed aromatic mechanisms (MCMv3 and MCMv3.1) against environmental chamber data, Atmos. Chem. Phys., 5, 623-639, 2005, http://www.atmos-chem-phys.net/5/623/2005/.

Carslaw, D. C. and Beevers, S. D.: Estimation of road vehicle primary $\mathrm{NO}_{2}$ exhaust emission fractions using monitoring data in London, Atmos. Environ., 39, 167-177, 2005.

Cheng, Y., Wang, X., Liu, Z., Bai, Y., Li, J.: A new method for quantitatively characterizing atmospheric oxidation capacity, Sci. China Ser. B-Chem., 51, 1102-1109, 2008.

Curtis, A. R. and Sweetenham, W. P.: FACSIMILE/CHEKMAT users manual, Rep. AERER12805, Her Majesty's Stn. Off Norwich, UK, 1987.

Diaz, S., Camilion, C., Deferrari, G., Fuenzalida, H., Armstrong, R., Booth, C., Paladini, A., Cabrera, S., Casiccia, C., Lovengreeng, C., Pedroni, J., Rosales, A., Zagarese, H., and Vernet, M.: Ozone and UV Radiation over Southern South America: Climatology and Anomalies. Photochem. Photobiol., 82, 834-843, 2006.

Di Carlo, P., Brune, W. H., Martinez, M., Harder, H., Lesher, R., Ren, X., Thornberry, T., Carroll, M. A., Young, V., Shepson, P. B., Riemer, D., Apel, E., and Campbell, C.: Missing OH reactivity in a forest: Evidence for unknown reactive biogenic VOCs, Science, 304, 722-725, 2004.

Elshorbany, Y., Wiesen, P., Kleffmann, J., Kurtenbach, R., Rubio, R., Lissi, E., Villena, G., Rickard, A. R., and Pilling, M. J.: Analysis and simulation of the ozone photochemical formation in Santiago de Chile. In preparation, 2009.

Emmerson, K. M., Carslaw, N., Carpenter, L. J., Heard, D. E., Lee, J. D., and Pilling, M. J.: Urban atmospheric chemistry during the PUMA campaign 1: Comparison of modelled $\mathrm{OH}$ and $\mathrm{HO}_{2}$ concentrations with measurements, J. Atmos. Chem., 52, 143164, 2005a.

Emmerson, K. M., Carslaw, N., and Pilling, M. J.: Urban Atmospheric Chemistry during the PUMA Campaign. 2: Radical budgets for $\mathrm{OH}, \mathrm{HO}_{2}$ and $\mathrm{RO}_{2}$, J. Atmos. Chem., 52, 165-183, 2005b.

Emmerson, K. M., Carslaw N., Carslaw D. C., Lee, J. D., McFiggans, G., Bloss, W. J., Gravestock, T., Heard, D. E., Hopkins, J., Ingham, T., Pilling, M. J., Smith, S. C., Jacob, M., and Monks, P. S.: Free radical modelling studies during the UK TORCH Campaign in summer 2003, Atmos. Chem. Phys., 7, 167-181, 2007, http://www.atmos-chem-phys.net/7/167/2007/.
Finlayson-Pitts, B. J., Wingen, L. M., Sumner, A. L., Syomin, D., and Ramazan, K. A.: The Heterogeneous Hydrolysis of $\mathrm{NO}_{2}$ in Laboratory Systems and in Outdoor and Indoor Atmospheres: An Integrated Mechanism, Phys. Chem. Chem. Phys., 5, 223 242, 2003.

Friedfeld, S., Fraser, M., Ensor, K., Tribble, S., Rehle, D., Leleux, D., and Tittel, F.: Statistical analysis of primary and secondary atmospheric formaldehyde, Atmos. Environ., 36, 4767-4775, 2002.

Garcia, A. R., Volkamer, R., Molina, L. T., Molina, M. J., Samuelson, J., Mellqvist, J., Galle, B., Herndon, S. C., and Kolb, C. E.: Separation of emitted and photochemical formaldehyde in Mexico City using a statistical analysis and a new pair of gas-phase tracers, Atmos. Chem. Phys., 6, 4545-4557, 2006, http://www.atmos-chem-phys.net/6/4545/2006/.

George, L. A., Hard, T. M., and O'Brien, R. J.: Measurement of free radicals $\mathrm{OH}$ and $\mathrm{HO}_{2}$ in Los Angeles smog, J. Geophys. Res., 104(D9), 11643-11656, 1999.

George, C., Strekowski, R. S., Kleffmann, J., Stemmler, K., and Ammann, M.: Photoenhanced Uptake of Gaseous $\mathrm{NO}_{2}$ on Solid Organic Compounds: A Photochemical Source of HONO?, Faraday Discuss., 130, 195-210, 2005.

Geyer, A., Alicke, B., Konrad, S., Schmitz, T., Stutz, J. and Platt, U.: Chemistry and oxidation capacity of the nitrate radical in the continental boundary layer near Berlin, J. Geophys. Res., 106, 8013-8025, 2001.

Gutzwiller, L., Arens F., Baltensperger, U., Gäggeler, H. W., and Ammann, M.: Significance of Semivolatile Diesel Exhaust Organics for Secondary HONO Formation, Environ. Sci. Technol., 36, 677-682, 2002.

Harrison, R. M., Yin, J., Tilling, R. M., Cai, X., Seakins, P.W., Hopkins, J. R., Lansley, D. L., Lewis, A. C., Hunter, M. C., Heard, D. E., Carpenter, L. J., Creasey, D. J., Lee, J. D., Pilling, M. J., Carslaw, N., Emmerson, K. M., Redington, A., Derwent, R. G., Ryall, D., Mills, G., and Penkett, S. A.: Measurement and modelling of air pollution and atmospheric chemistry in the UK west midlands conurbation: overview of the PUMA consortium project, Sci. Total Environ., 360, 5-25, 2006.

Hayman, G. D.: Effects of Pollution Control on UV Exposure. AEA Technology Final Report (Ref: AEA/RCEC/22522001/R/002 Issue 1) AEA Technology, Oxfordshire, UK, 1997.

Heard, D. E., Carpenter, L. J., Creasey, D. J., Hopkins, J. R., Lee, J. D., Lewis, A. C., Pilling, M. J., Seakins, P. W., Carslaw, N., and Emmerson, K. M.: High levels of the hydroxyl radical in the winter urban troposphere, Geophys. Res. Lett., 31, L18112, 2004.

Heland, J., Kleffmann, J., Kurtenbach, R., and Wiesen, P.: A New Instrument to Measure Gaseous Nitrous Acid (HONO) in the Atmosphere, Environ. Sci. Technol., 35, 3207-3212, 2001.

Holland, F., Hofzumahaus, A., Schäfer, J., Kraus, A., and Pätz, H.W.: Measurements of $\mathrm{OH}$ and $\mathrm{HO}_{2}$ Radical Concentration and Photolysis Frequencies during BERLIOZ, J. Geophys. Res., 180, 8246, doi:10.1029/2001JD001393, 2003.

Huang, G., Zhou, X., Deng, G., Qiao, H., and Civarolo, K.: Measurements of atmospheric nitrous acid and nitric acid, Atmos. Environ., 36, 2225-2235, 2002.

Jenkin, M. E., Saunders, S. M., and Pilling, M. J.: The tropospheric degradation of volatile organic compounds: a protocol for mechanism development, Atmos. Environ., 31, 81-104, 1997. 
Jenkin, M. E., Saunders, S. M., Wagner, V., and Pilling, M. J.: Protocol for the development of the Master Chemical Mechanism, MCM V3 (Part B): tropospheric degradation of aromatic volatile organic compounds, Atmos. Chem. Phys., 3, 181-193, 2003, http://www.atmos-chem-phys.net/3/181/2003/.

Johnson, D. and Marston, G.: The gas-phase ozonolysis of unsaturated volatile organic compounds in the troposphere, Chem. Soc. Rev., 37, 699-716, 2008.

Kanaya, Y., Cao, R., Akimoto, H., Fukoda, M., Komazaki, Y., Yokouchi, Y., Koike, M., Tanimoto, H., Takegawa, N., and Konodo, Y.: Urban photochemistry in central Tokyo: 1. Observed and modelled $\mathrm{OH}$ and $\mathrm{HO}_{2}$ radical concentrations during the winter and summer of 2004, J. Geophys. Res., 112, D21312, doi:10.1029/2007JD008670, 2007.

Kleffmann, J., Heland, J., Kurtenbach, R., Lörzer, J. C., and Wiesen, P.: A New Instrument (LOPAP) for the Detection of Nitrous Acid (HONO), Environ. Sci. Technol., 9(4), 48-54, 2002.

Kleffmann, J., Kurtenbach, R., Lörzer, J. C., Wiesen, P., Kalthoff, N., Vogel, B., and Vogel, H.: Measured and simulated vertical profiles of nitrous acid Part I: Field measurements, Atmos. Environ., 37, 2949-2955, 2003.

Kleffmann, J., Gavriloaiei, T., Hofzumahaus, A., Holland, F., Koppmann, R., Rupp, L., Schlosser, E., Siese, M., and Wahner, A.: Daytime Formation of Nitrous Acid: A Major Source of OH Radicals in a Forest, Geophys. Res. Lett., 32, L05818, doi:10.1029/2005GL022524, 2005.

Kleffmann, J., Lörzer, J. C., Wiesen, P., Kern, C., Trick, S., Volkamer, R., Rodenas, M., and Wirtz, K.: Intercomparisons of the DOAS and LOPAP Techniques for the Detection of Nitrous Acid (HONO) in the Atmosphere, Atmos. Environ., 40, 3640-3652, 2006.

Kleffmann, J.: Daytime Sources of Nitrous Acid (HONO) in the Atmospheric Boundary Layer, Chem. Phys. Chem., 8, 1137-1144, 2007.

Kleffmann, J. and Wiesen, P.: Technical Note: Quantification of interferences of wet chemical HONO LOPAP measurements under simulated polar conditions, Atmos. Chem. Phys., 8, 6813-6822, 2008 ,

http://www.atmos-chem-phys.net/8/6813/2008/.

Koppmann, R., Johnen, F. J., Khedim, A., Rudolph, J., Wedel, A., and Wiards, B.: The influence of ozone on light nonmethane hydrocarbons during cryogenic preconcentration, J. Geophys. Res., 100, 11383-11391, 1995.

Kurtenbach, R., Becker, K. H., Gomes, J. A. G., Kleffmann, J., Lörzer, J. C., Spittler, M., Wiesen, P., Ackermann, R., Geyer, A., and Platt, U.: Investigation of Emissions and Heterogeneous Formation of HONO in a Road Traffic Tunnel, Atmos. Environ., 35, 3385-3394, 2001.

Li, S., Matthews, J., and Sinha, A.: Atmospheric Hydroxyl Radical Production from Electronically Excited $\mathrm{NO}_{2}$ and $\mathrm{H}_{2} \mathrm{O}$, Science, 319, 1657-1660, 2008.

Liu, S. C., Cox, R. A., Crutzen, P. J., Ehhalt, D. H., Guicherit, R., Hofzumahaus, A., Kley, D., Penkett, S. A., Phillips, L. F., Poppe, D., and Rowland, F. S.: Group Report: Oxidizing Capacity of the atmosphere, in: The Changing Atmosphere, edited by: Rowland, F. S. and Isaksen, I. S. A., Wiley, Chichester, UK, 219-232, 1988.

Mihelcic, D., Holland, F., Hofzumahaus, A., Hoppe, L., Konrad, S., Müsgen, P., Pätz, H.-W., Schäfer, H.-J., Schmitz, T., Volz-Thomas, A., Bächmann, K., Schlomski, S., Platt, U.,
Geyer, A., Alicke, B., and Moortgat, G.: Peroxy radicals during BERLIOZ at Pabstthum: Measurements, radical budgets and ozone production, J. Geophys. Res., 108(D4), 8254, doi:10.1029/2001JD001014, 2003.

Niedojadlo, A., Becker, K. H., Kurtenbach, R., and Wiesen P.: The contribution of traffic and solvent use to the total NMVOC emission in a German city derived from measurements and CMB modelling, Atmos. Environ., 41(33), 7108-7126, 2007.

Paulson, S. E. and Orlando, J. J.: The reactions of ozone with alkenes: An important source of HOx in the boundary layer, Geophys. Res. Lett., 23, 3727, 1996.

Prinn, G. R.: The cleansing capacity of the atmosphere, Ann. Rev. Environ. Resour., 28, 29-57, 2003.

Rappenglück, B., Oyola, P., Olaeta, I., and Fabian, P.: The evaluation of photochemical smog in the metropolitan area of Santiago de Chile, J. Appl. Meteorol., 39, 275-290, 2000.

Rappenglück, B., Schmitz, R., Bauerfeind, M., Cereceda-Balic, F., von-Baer, D., Jorquera, H., Silva, Y., and Oyola, P.: An Urban Photochemistry study in Santiago de Chile, Atmos. Environ., 39, 2913-2931, 2005.

Ren, X., Harder, H., Martinez, M., Lesher, R. L., Oliger, A., Simpas, J. B., Brune, W. H., Schwab, J. J., Demerjian, K. L., He, Y., Zhou, X., and Gao, H.: $\mathrm{OH}$ and $\mathrm{HO}_{2}$ Chemistry in the Urban Atmosphere of New York City, Atmos. Environ., 37, 3639-3651, 2003.

Ren, X., Brune, W. H., Mao, J., Mitchell, M. J., Lesher, R. L., Simpas, J. B., Metcalf, A. R., Schwab, J.J., Cai, C., Li, Y., Demerjian, K. L., Felton, H. D., Boynton, G., Adams, A., Perry, J., He, Y., Zhou, X., and Hou, J.: Behavior of $\mathrm{OH}$ and $\mathrm{HO}_{2}$ in the Winter Atmosphere in New York City, Atmos. Environ., 40, Supplement 2, 252-263, 2006.

Rickard, A. R., Johnson, D., McGill, C. D., and Marston, G.: OH yields in the gas-phase reactions of ozone with alkenes, J. Phys. Chem., A103, 7656-7664, 1999.

Rohrer, F. and Berresheim, H.: Strong correlation between levels of tropospheric hydroxyl radicals and solar ultraviolet radiation, Nature 442, 184-187, doi:10.1038/nature04924, 2006.

Rubio, M. A., Oyola, P., Gramsch, E., Lissi, E., Pizzaro, J., and Villena, G.: Ozone and peroxyacetylnitrate in downtown Santiago, Chile, Atmos. Environ., 38, 4931-4939, 2004.

Rubio, M. A., Lissi, E., Villena, G., Caroca, V., Gramsch, E., and Ruiz A.: Estimation of hydroxyl and hydroperoxyl radicals concentrations in the urban atmosphere of Santiago, J. Chilean Chem. Soci., 50, 2, 375-379, 2005.

Rubio, M. A., Zamorano, N., Lissi, E., Rojas, A., Gutierrez, L., and von Bare, D.: Volatile carbonyl compounds in downtown Santiago, Chile, Chemosphere, 62, 1011-1020, 2006.

Saunders, S. M., Jenkin, M. E., Derwent, R, G., and Pilling, M. J.: Protocol for the development of the Master Chemical Mechanism, MCM V3: tropospheric degradation of non-aromatic VOC, Atmos. Chem. Phys., 3, 161-180, 2003, http://www.atmos-chem-phys.net/3/161/2003/.

Sillman, S.: The relation between ozone, $\mathrm{NO}_{\mathrm{x}}$ and hydrocarbons in urban and polluted rural environments, Atmos. Environ., 33, 1821-1845, 1999.

Shirley, T. R., Brune, W. H., Ren, X., Mao, J., Lesher, R., Cardenas, B., Volkamer, R., Molina, L. T., Molina, M. J., Lamb, B., Velasco, E., Jobson, T., and Alexander, M.: Atmospheric oxidation in the Mexico City Metropolitan Area (MCMA) during 
April 2003, Atmos. Chem. Phys., 6, 2753-2765, 2006, http://www.atmos-chem-phys.net/6/2753/2006/.

Sheehy, P. M., Volkamer, R., Molina, L. T., and Molina, M. J.: Oxidative capacity of the Mexico City atmosphere - Part2: A $\mathrm{RO}_{\mathrm{x}}$ radical cycling perspective, Atmos. Chem. Phys. Discuss., 8, 5359-5412, 2008, http://www.atmos-chem-phys-discuss.net/8/5359/2008/.

Spindler, G., Hesper, J., Brüggemann, E., Dubois, R., Müller, T., and Herrmann, H.: Wet Annular Denuder Measurements of Nitrous Acid: Laboratory Study of the Artefact Reaction of $\mathrm{NO}_{2}$ with S(IV) in Aqueous Solutions and Comparison with Field Measurements, Atmos. Environ., 37, 2643-2662, 2003.

Stemmler, K., Ammann, M., Dondors, C., Kleffmann, J., and George, C.: Photosensitized Reduction of Nitrogen Dioxide on Humic Acid as a Source of Nitrous Acid, Nature, 440, 195-198, 2006.

Stemmler, K., Ndour, M., Elshorbany, Y., Kleffmann, J., D’Anna, B., George, C, Bohn, B., and Ammann, M.: Light induced conversion of nitrogen dioxide into nitrous acid on submicron humic acid aerosol, Atmos. Chem. Phys., 7, 4237-4248, 2007, http://www.atmos-chem-phys.net/7/4237/2007/.

Stockwell, W. R., Kirchner, F., Kuhn, M. and Seefeld, S.: A new mechanism for regional atmospheric chemistry modelling, J. Geophys. Res., 102(D22), 25847- 25880, 1997.

Stutz, J., Alicke, B., and Neftel, A.: Nitrous Acid Formation in the Urban Atmosphere: Gradient Measurements of $\mathrm{NO}_{2}$ and $\mathrm{HONO}$ over Grass in Milan, Italy, J. Geophys. Res., 107 (D22), 8192, doi:10.1029/2001JD000390, 2002.
Stutz, J., Alicke, B., Ackermann, R., Geyer, A., Wang, S. H., White, A. B., Williams, E. J., Spicer, C. W., and Fast, J. D.: Relative humidity dependence of HONO chemistry in urban areas, J. Geophys. Res., 109, D03307, doi:10.1029/2003JD004135, 2004.

Vogel, B., Vogel, H., Kleffmann, J., and Kurtenbach, R.: Measured and Simulated Vertical Profiles of Nitrous Acid, Part II - Model Simulations and Indications for a Photolytic Source, Atmos. Environ., 37, 2957-2966, 2003.

Volkamer, R., Sheehy, P. M., Molina, L. T., and Molina, M. J.: Oxidative capacity of the Mexico City atmosphere - Part 1: A radical source perspective, Atmos. Chem. Phys. Discuss., 7, 53655412, 2007, http://www.atmos-chem-phys-discuss.net/7/5365/2007/.

Yoshino, A., Sadanagab, A., Watanabea, K., Katoa, S., Miyakawaa, Y., Matsumotoc, J., and Kajiia, Y.: Measurement of total $\mathrm{OH}$ reactivity by laser-induced pump and probe techniquecomprehensive observations in the urban atmosphere of Tokyo, Atmos. Environ., 40, 7869-7881, 2006.

Zhou, X., Civerolo, K., Dai, H., Huang, G., Schwab, J., and Demerjian, K.: Summertime Nitrous Acid Chemistry in the Atmospheric Boundary Layer at a Rural Site in New York State, J. Geophys. Res., 107(D21), 4590, doi:10.1029/2001JD001539, 2002.

Zhou, X., Gao, H., He, Y., Huang, G., Bertman, S. B., Civerolo K., and Schwab, J.: Nitric Acid Photolysis on Surfaces in Low-NO Environments: Significant Atmospheric Implications, Geophys. Res. Lett., 30(23), 2217, doi:10.1029/2003GL018620, 2003. 